\title{
AÇÃO COLETIVA, ACCOUNTABILITY SOCIAL E GOVERNANÇA DEMOCRÁTICA NA CONSTRUÇÃO DE CIDADES SUSTENTÁVEIS: OS CASOS DE ILHABELA, ILHÉUS E FLORIANÓPOLIS ${ }^{\mathrm{T}}$
}

\author{
"COLLECTIVE ACTION, SOCIAL ACCOUNTABILITY AND DEMOCRATIC \\ GOVERNANCE IN THE CONSTRUCTION OF SUSTAINABLE CITIES: A MULTIPLE \\ CASE STUDY IN ILHABELA, ILHÉUS AND FLORIANÓPOLIS”
}

\section{Jeferson Dahmer ${ }^{2}$}

RESUMO: A América Latina presenciou, nas últimas duas décadas, o surgimento de iniciativas da sociedade civil voltadas ao monitoramento do poder público, à produção e à sistematização de informações, ao desenvolvimento de pesquisas de percepção cidadã e à qualificação da participação. Expressões desse fenômeno são a Red Ciudades Cómo Vamos, a Red Latino-americana por Ciudades y Territorios Justos, Democráticos y Sustentables e sua correlata brasileira. Este trabalho buscou compreender em que medida as experiências de três cidades brasileiras - Florianópolis, Ilhabela e Ilhéus -, que integram a rede latinoamericana e brasileira, entendidas enquanto ações coletivas, expressam e influenciam a governança e o sistema de accountability, gerando incidência nas instituições políticas e em outros âmbitos. A pesquisa, de cunho qualitativo e interpretativo, coletou dados in loco, na participação em reuniões e encontros promovidos pelas experiências, além da realização de 25 entrevistas com lideranças e grupos participantes, incluindo o poder público local. $\mathrm{O}$ modelo de análise foi construído a partir da teoria da mobilização política e sua categoria analítica do confronto político, articulando-as aos referenciais sobre governança democrática e perspectivas de accountability associadas. Os resultados apontam para a mútua influência entre governança democrática e accontability. Ao mesmo tempo em que as iniciativas representam novos atores na governança, evidenciam estratégias de fortalecimento dos canais já existentes, demostrando novas possibilidades e modalidades

\footnotetext{
${ }^{1}$ Agradeço à Coordenação de Aperfeiçoamento de Pessoal de Nível Superior (CAPES) pela concessão da Bolsa de Produtividade em Pesquisa e ao Conselho Nacional de Desenvolvimento Científico e Tecnológico (CNPq) pelo apoio financeiro concedido na realização do estudo. A Professora Orientadora e Coordenadora da Pesquisa "Governança Democrática em Cidades Latinoamericanas: Estudo Comparado de Experiências de Accountability Social e sua Incidência em Cidades Argentinas, Brasileiras Colombianas e Uruguaias" (Chamada 43/2013 - MCTI/CNPq/MEC/CAPES), Dra. Paula Chies Schommer (UDESC/ESAG). Ao Grupo de Pesquisa Politeia da UDESC/ESAG. As avaliadoras Adina Dudau, PhD (University of Glasgow) e Susan Philips, PhD (Carleton University) por ocasião da apresentação e premiação da versão em inglês do artigo durante a XIX International Research Society for Public Management - IRSPM Birmingham/2015 - Categoria New Researchers. Aos Professores: Dra. Carolina Andion (UDESC/ESAG), Dr. Andres Hernandez Quinõnes Universidad de Los Andes), Dr. Teo Armindo dos Santos Teodósio (PUC/MG) e Dra. Pamela Cáceres (Universidad Católica de Córdoba) pelas valiosas contribuições. As lideranças de todas as iniciativas pela receptividade à Pesquisa.

${ }^{2}$ Mestre em Administração - Organizações e Esfera Pública pela Universidade do Estado de Santa CatarinaUDESC/ESAG. E-mail: jeffedahmer@gmail.com
} 
de accountability, como a social. A incidência é observada em âmbitos como: agenda local, governança da cidade, instituições políticas, debate político eleitoral, políticas públicas, organizações parceiras e pessoas.

Palavras-chave: Ação Coletiva. Accountability Social. Governança Democrática. Mobilização Política. Confronto Político.

ABSTRACT: In the last two decades, Latin America witnessed the emergence of civil society initiatives aimed at monitoring public administration, qualifying citizen participation, the production and systematization of information, the development of citizen perception surveys. Leading this phenomenon are networks Red de Ciudades Cómo Vamos, Red Latino-americana por Ciudades y Territorios Justos, Democráticos y Sustentables and its related Brazilian network. This work is the result of a master thesis that aimed to understand the extent of the experiences of three Brazilian cities Florianópolis, Ilhabela and Ilhéus, comprising the Brazilian and Latin American network, understood as collective action and expressing and influencing governance and the accountability system, generating incidence in political institutions and in other areas. The research is a qualitative and interpretive study. Data was collected in loco, in the participation of meetings and workshops that occurred through experiences, as well as conducting 25 interviews with leaders and participating groups, including local government. The analysis model was constructed from the theory of collective action of political mobilization and your analytical category of contencious politics, linking them to references about democratic governance and prospects for associated accountability. The results show the mutual influence between democratic governance and accountability. While they represent new actors in governance, they show strategies for strengthening existing governance channels, demonstrating new possibilities and forms of accountability, such as social. Incidence is observed in areas such as: local agenda, city governance, political institutions, political and electoral debate, public policy, partner organizations and people.

Keywords: Collective Action. Social Accountability. Democratic Governance. Political Mobilization. Contencious Politics.

\section{Contextualização do fenômeno e da pesquisa}

Este trabalho reúne as principais discussões e conclusões da dissertação de mestrado acadêmico do autor, intitulada "Ação coletiva, governança democrática e accountability social na construção de cidades sustentáveis: os casos de Florianópolis, Ilhabela e Ilhéus". Interessou conhecer, na proposta de estudo, as imbricações conceituais e empíricas entre estas três experiências, que integram a Rede Social Brasileira por Cidades Justas, Democráticas e Sustentáveis (RSBCJDS), entendidas enquanto ações coletivas e sua relação com os conceitos de accountability e governança democrática. 
A dissertação teve como pergunta de pesquisa: Como emergem e se estruturam as açoes coletivas dos movimentos de cidades justas, democráticas e sustentáveis em Ilhéus, Ilhabela e Florianópolis, incidindo sobre a governança democrática e a accountability? A teoria da ação coletiva da mobilização política desenvolvida por Sidney Tarrow (2009) no livro "O poder em movimento" serviu como ponto de partida para a construção do modelo de análise. O cunho do trabalho foi de natureza qualitativa e interpretativa, de acordo com a abordagem de delineamento de pesquisa de Deslauriers e Kérisit (2008). Nessa perspectiva, o referencial teórico, a representação do modelo, a escolha da teoria e as análises foram desenvolvidos em interação com o campo, sendo realizadas 25 entrevistas, nas três cidades.

A escolha pelas três experiências é justificada pela participação do pesquisador na iniciativa do Movimento Floripa te Quero Bem (Florianópolis - SC) e pelas semelhanças geográficas e naturais entre os ecossistemas das cidades de Ilhabela - SP (Instituto Nossa Ilhabela Sustentável) e Ilhéus - BA (Instituto Nossa Ilhéus) com Florianópolis, aliada à possibilidade de identificar a existência de problemas urbanos comuns, além de fatos geradores das ações coletivas, projetos realizados e metodologias compartilhadas no trabalho em rede.

Destaca-se, também, o interesse pelas experiências, no quadro de uma pesquisa maior - "Governança Democrática em Cidades Latinoamericanas: Estudo Comparado de Experiências de Accountability Social e sua Incidência em Cidades Argentinas, Brasileiras, Colombianas e Uruguaias" (Chamada № 43/2013 - MCTI/CNPq/MEC/CAPES), em aprofundar os conhecimentos sobre tais temáticas e sobre as três cidades, localizadas em diferentes regiões do país, com distintas características sociais, econômicas e políticas, seguida pela representatividade das iniciativas na rede brasileira.

As três experiências analisadas se inserem e são influenciadas por um contexto social e político latino-americano que tem levado ao surgimento de iniciativas similares, bem como sua organização em rede nos países da região. Expressões desta dinâmica, em curso, são a "Red de Ciudades Cómo Vamos", a "Red Latinoamericana por Ciudades y Territorios Justos, Democráticos y Sustentables” e sua correlata brasileira.

A Rede dos "Cómo Vamos" é a experiência pioneira no continente. Teve sua origem em Bogotá, capital da Colômbia, em 1998, sendo conduzida por representantes 
empresariais, terceiro setor, meios de comunicação e universidades, após a constatação da inexistência de meios adequados de planejamento e acompanhamento da gestão pública. Outras cidades colombianas inspiraram-se no modelo e deram origem a "Red de Ciudades Cómo Vamos", que hoje integra outras cidades do país, como Barranquilla, Manizales, Pereira, Medellín, Valledupar, Cartagena, Bucaramanga, Ibagué e Cali (RED CÓMO VAMOS, 2014).

No Brasil, ação semelhante à experiência da capital colombiana começou a estruturar-se a partir do final de 2006, sendo lançado, em maio de 2007, o Movimento Nossa São Paulo (ETHOS, 20ı4a; FIABANE, 2orı; FIABANE, ALVES e BRELÀZ, 20r4; FUNDAÇÃO AVINA, 2010; PEREIRA, 2014; REDE NOSSA SÃO PAULO, 2014a). Algumas lideranças do Movimento Nossa São Paulo tomaram conhecimento da experiência de Bogotá e um grupo de empresários, a convite da Fundação Avina, partiram para uma visita técnica à cidade colombiana (Entrevistado o7 - Rede Nossa São Paulo). O modelo de inovação cívica serviu pois de inspiração para a criação do Movimento Nossa São Paulo, que passou a se chamar Rede Nossa São Paulo, em outubro de 2010 (PEREIRA, 2014; FIABANE, 2011; FIABANE, ALVES e BRELÀZ, 2014; RNSP, 2014). Na esteira deste processo, as iniciativas alcançaram outras cidades, em todo o país, culminando com o lançamento da Rede Brasileira por Cidades Justas, Democráticas e Sustentáveis, em 2008, em Belo Horizonte, com a participação de vinte munícipios brasileiros (ETHOS, 2009).

Enquanto a rede brasileira se constituía, processos similares aconteciam em outros países da América Latina, o que levou à constituição, em 2009, da Red Latinoamericana por Ciudades y Territorios Justos, Democráticos y Sustentables, que conta hoje com mais de 6o iniciativas em ro países do continente latino-americano (RLACTJDS, 2014a), a saber: Argentina; Bolívia; Brasil; Chile; Colômbia; Equador; México; Paraguai; Peru; e Uruguai.

Em espectro amplo sobre as experiências de participação e democracia na América Latina, nas últimas décadas, Insunza e Gurza (2010) destacam que a sociedade civil latinoamericana tem inovado em seus processos de controle sobre as instituições e sobre as práticas políticas. Para os autores, há duas razões centrais pelas quais estas iniciativas de controle cidadão, que se multiplicam no continente, são diferentes das formas tradicionais de representação política: (i) elas não são mediadas por autorização, nem por mandato 
específico (delegação); (ii) são formas de representação difusa, ou seja, os atores presumem ou supõem representar os interesses de grupos particulares ou da sociedade civil em geral.

Hernandez Quinõnes e Devilchez (2014), compartilham da reflexão de Isunza e Gurza (2010) destacando que os atores ligados a estas redes específicas representam uma nova forma de expressão e representação política, compartilhando um discurso comum relativo a democracia e sustentabilidade, enfatizando aspectos políticos e instrumentais como transparência, acesso à informação e desenvolvimento de sistemas voltados a sua produção e sistematização, exigência de prestação de contas e incentivo a sanções sociais e culturais, a realização de pesquisas de percepção cidadã e à constituição de observatórios de monitoramento dos poderes público e privado, tendo as cidades, como lócus de sua ação.

Cáceres (2014) leciona que a ação política destas redes de cidades é traduzida em seu objetivo político (repertório): Ciudades y Territorios Justos, Democráticos y Sustentables. A autora assim sistematiza suas principais linhas de ação: (a) Monitorar a situação das cidades no que se relaciona a qualidade de vida, justiça social, democracia e sustentabilidade; (b) Promover a participação cidadã e o ativismo político; (c) Monitorar e incidir em políticas públicas; (d) Promover espaços de diálogo entre a sociedade civil e atores privados, estabelecendo uma interlocução permanente com o Estado; (e) Democratizar a informação e o conhecimento para que se promova uma participação qualificada da cidadania nos processos e nas instâncias de tomada de decisão.

A partir destas linhas de ação, Cáceres (2014) destaca que estas iniciativas colocam em evidência a valorização do acesso à informação, não apenas disponibilizando-a, mas democratizando o seu acesso e, por consequência, promovendo a transparência e gerando condições para a accountability. Para a autora, a articulação destas redes de ação coletiva e a construção de consensos e posicionamentos sobre a realidade das cidades é que permitirá as transformações necessárias às instituições públicas. Transformações que, segundo a autora, efetivam-se a partir de uma cidadania ativa que visa se reapropriar da política, fortalecendo os processos de governança local e regional.

Partindo-se deste contexto é que, em termos teórico-empíricos, buscou-se estabelecer uma conexão entre a práxis destas redes e os conceitos de ação coletiva, governança e accountability, analisando as experiências de Ilhéus, Ilhabela e Florianópolis. 


\section{Mobilização Política, Perspectivas de Accountability e Governança Democrática}

\section{I Confronto Político e Mobilização Política}

De acordo com Gohn (2010) e Carlos (2011), a teoria da ação coletiva da mobilização política, como se convencionou chamar no Brasil, está relacionada ao conceito de contentious politics (confronto político) de Tarrow (2009). Em linhas gerais, o conceito se refere a um conjunto de condições que leva determinados grupos da sociedade a se envolver em um processo contencioso. Quando um quadro de restrições e oportunidades políticas se evidencia, circunscrito a um contexto, surge uma ação coletiva, que sustentada, leva a movimentos sociais (TARROW, 2009). Para Tarrow (p. 39, 2009) "o confronto não nasce da cabeça dos organizadores, mas está culturalmente inscrito e é socialmente comunicado", e "no futuro, dependerá não de quão violento ou disseminado tenha se tornado o confronto, mas de como ele for absorvido no - e transformar o - Estado nacional" (p. 26).

Evidenciado o quadro de oportunidades e restrições políticas, para Tarrow (2009), uma ação coletiva se sustenta quando três condições são identificadas: repertórios, mobilização de estruturas e forma. Os repertórios representam os marcos referenciais e estratégicos dos movimentos, transmitem seus significados, sua orientação valorativa, seus símbolos. Eles colocam em evidência o que dá sentido às suas ações. A mobilização de estruturas expressa as estratégias e os instrumentos utilizados no processo de mobilização social e de articulação dos atores da ação coletiva. A forma diz respeito ao como a ação coletiva se processa ou se posiciona em um contexto, refletindo as características deste contexto e do período histórico. Pode assumir três formas principais: a violência, a ruptura ou a convenção.

Uma ação coletiva sustentada, a depender do contexto, pode evoluir para um ciclo de confronto. Nesse caso, houve uma generalização do confronto e o quadro de restrições e oportunidades políticas já reverberou nas estruturas do poder. Em um ciclo de confronto os atores da ação coletiva começam a articular-se em redes sociais que levam a "ondas de confronto maiores" (TARROW, p. I8I, 2009) que podem levar à difusão da ação coletiva, 
ao aumento na troca de informação e interação entre diferentes atores, bem como à sua desmobilização.

Quando os ciclos de confronto se difundem, o repertório se fortalece e unifica, possibilitando o surgimento de confrontos transnacionais, que permitem a replicabilidade da ação coletiva e dos movimentos sociais (TARROW, 2009). Em síntese, um ciclo de confronto começa com a incitação-percepção de indivíduos contra algo (confronto político). Em seguida ocorre a disseminação do confronto político pelo repertório, mobilizando estruturas locais e até mesmo nacionais, cooperando com o objeto de confronto já sustentado (ciclos de confronto). Por fim, quando surge uma representação transnacional, leva-se adiante as reivindicações do confronto político para a esfera global (TARROW, 2009; COHEN, 2003), delineando-se o confronto transnacional. Nas palavras de Tarrow (2009), os movimentos sociais transnacionais representam "interações contenciosas sustentadas com opositores - nacionais ou não nacionais - através de redes de desafiantes organizados que ultrapassam as fronteiras nacionais.” (p. 23I).

Sob esta lógica, Cohen (2003) leciona sobre a existência de uma sociedade civil global. Tarrow (2009), ao desenvolver seu conceito de ação coletiva, destaca, como Cohen (2003), o surgimento de redes transacionais colocando em evidência problemas e agendas comuns. Sobre este ponto, Cohen (2003) leciona que tanto as problemáticas comuns como a percepção da natureza transnacional dos riscos colocam em conexão atores internacionais diversos, evidenciando que o "estado nacional, democrático, constitucional e soberano não parece mais ser a fonte legítima e exclusiva das mais importantes decisões vinculativas (...).” (p. 421).

É neste contexto que, para Cohen (2003), o surgimento do conceito de Governança sintetiza tais dinâmicas, pois as decisões e a responsabilidade pela condução dos assuntos coletivos e da sociedade deixa de ser atributo exclusivo das agências governamentais. Uma pluralidade de atores, reunida em rede, traz seus interesses, suas expertises e seus recursos, envolvendo-se no processo político e dispersando o poder nestas redes (DENHARDT, p. 270, 2012), possibilitando uma nova postura de engajamento, calcada em uma mudança no padrão de relacionamento entre Estado e sociedade civil (GAVENTA, 2002) e em novas perspectivas de accountability e controle democrático. 


\subsection{Accountability: da metáfora geométrica à abordagem social e suas imbricações com a governança democrática}

$\mathrm{O}$ arcabouço analítico da accountability tem levado a diferentes (re)interpretações. A trajetória e a emergência da perspectiva de accountability social surge a partir da constatação de que os regimes democráticos, estabelecidos após a redemocratização dos anos 1980, têm apresentado vários déficits institucionais, principalmente no que se refere ao desenvolvimento de mecanismos adequados e eficazes de accountability (PERUZZOTTI e SMULOVITZ, 2002; PERRUZZOTTI, 2012; GOETZ, 2003; ISUNZA e GURZA, 2ог; GOMÉZ e DELGADO, 20Ir; HERNANDEZ QUINÕNES, 20II; JIMÉNEZ, 2012). Tais indícios possibilitariam um repensar sobre a efetividade da clássica visão bidimensional (geométrica) de accountability, proposta por O’Donnel (1998): a accountability horizontal e vertical (PERUZZOTTI e SMULOVITZ, 2002, PERRUZZOTTI, 2012; HERNANDEZ QUINÕNES, 20II). E, nesse processo de (re)interpretação, os processos, instituições e atores que mobilizam a governança democrática têm papel decisivo (DENHARDT e DENHARDT, 2007; BEVIR, 20II).

O clássico trabalho de O’Donnel (1998) é ainda uma referência, ao mesmo tempo em que surgem novas qualificações ou ênfases ao termo: híbrida ou diagonal (GOETZ e JENKINS, 200I); transversal e social (PERUZZOTTI e SMULOVITZ, 2002; PERUZZOTTI, 2012; ISUNZA e GURZA, 2010; HERNANDEZ QUINÕNES, 20II); sistêmica (ROCHA et al, 2012), relacional (MONCRIEFFE, 20II).

A figura 2 a seguir ilustra os mecanismos de accountability trazidos por O'Donnel (1998) a partir de suas lógicas de interação. A accountability vertical se efetiva tanto pelo processo eleitoral, como pelas formas de controle social exercidas pelo cidadão sobre as diferentes instâncias do governo e da administração pública. Estas, por sua vez, orientamse a partir de uma lógica de ação e controle horizontal, cuja característica essencial é o exercício de pesos e contrapesos (Checks and Balances), representando os poderes constituídos e os órgãos de controle, auditoria e ouvidoria da própria administração.

Figura 2 - Esquema Accountability Horizontal e Vertical 


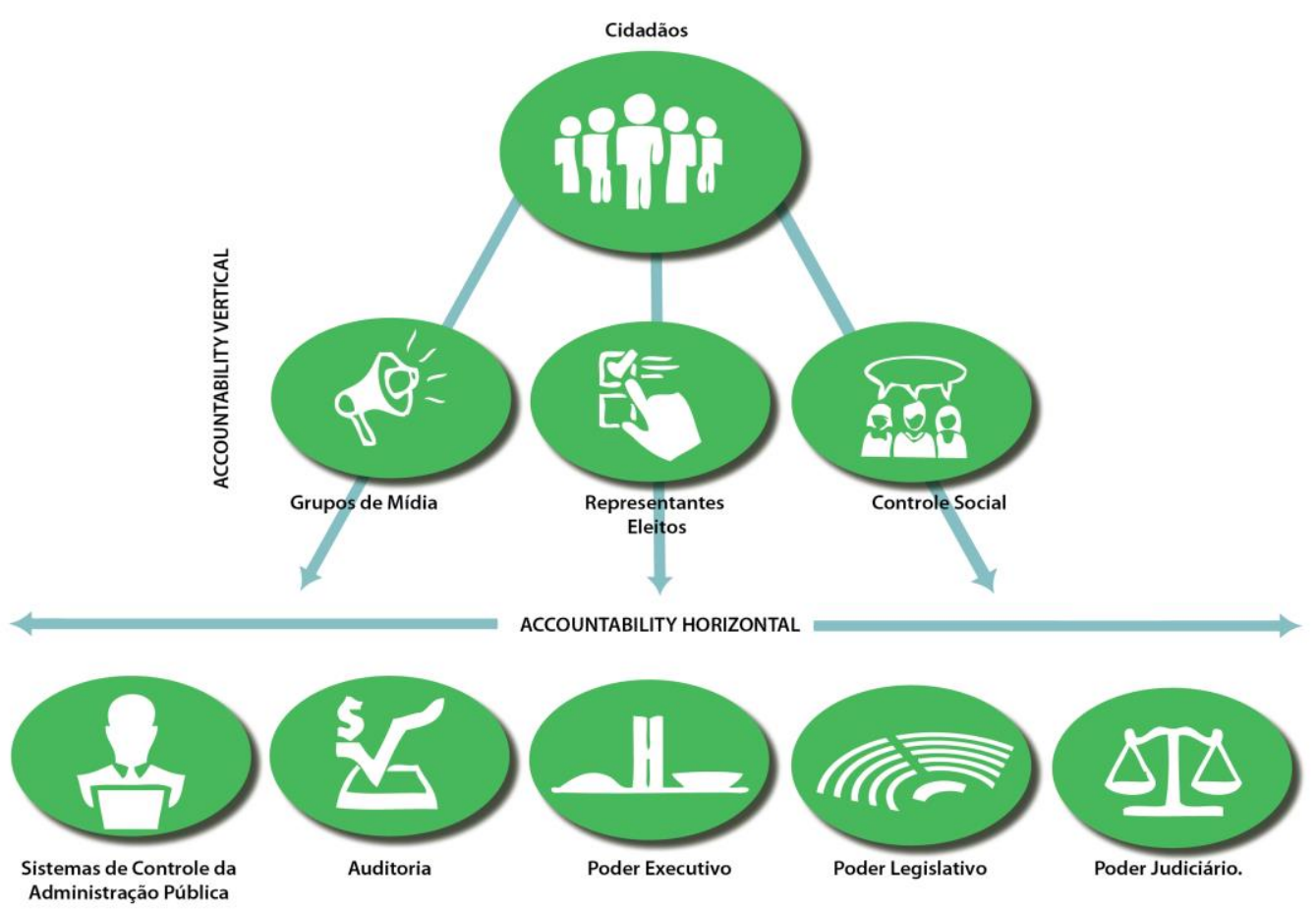

Fonte: Elaborado pelo autor, com base em United Nations - Fostering Social Accountability (2010)

$\mathrm{Na}$ abordagem de O’Donnel (1998), o controle social se efetiva por meio do acionamento e ativação das instituições que integram a accountability horizontal. Embora a mídia e o controle social tenham esse papel no modelo, sua atuação efetiva-se em grande parte a partir dos próprios canais e instrumentos estatais, abertos à participação da sociedade (HERNANDEZ QUINÕNES, 20II). Tal abordagem é diferente daquela que engloba uma variedade de formas de ação coletiva e ativismo cívico que compartilham o propósito de fortalecer os mecanismos de controle e melhorar o funcionamento das instituições representativas, a accountability social (PERUZZOTTI, 2012).

Para Peruzzotti e Smulovitz (2002) e Peruzzotti (2012), a forma tradicional de entender a accountability tem negligenciado, em grande medida, a contribuição da sociedade civil para o exercício do controle e para que a accountability social seja reconhecida como um espaço analítico que traz novas interpretações para as complexas relações que se estabelecem entre atores sociais e a política (PERUZZOTTI e SMULOVITZ, 2002, PERUZZOTTI, 2012; JIMÉNEZ, 2013). Compreender as democracias de hoje, na América 
Latina, segundo Peruzzotti e Smulovitz (2002), passa necessariamente pela análise dos fenômenos empíricos que têm na sociedade civil sua base de ação e inovação.

Jimenéz (2013) destaca que a accountability é um indicador da qualidade da democracia em um país. Para a autora, a accountability social pode ser compreendida como uma forma de fortalecimento da política, por permitir uma relação mais profunda entre governos, instituições, fundações, organismos multilaterais, cidadãos e meios de comunicação. Para Gómez e Delgado (p. 05, 20II), "distanciando-se de um entendimento dominante que associa a acountability ao âmbito das instituições democráticas, adiciona-se o termo 'social' para se referir ao papel da ação coletiva de organizações da sociedade civil na ampliação e fortalecimento da democracia”.

Nesta mesma linha, Goetz (2003) questiona: O que explica a emergência da perspectiva social da accountability? Para a autora, a onda de democratização dos anos 1980 e 1990 depositou grandes esperanças em grupos emergentes da sociedade civil em fazer valer seus direitos em uma era de governança. Soma-se a isso o contexto de globalização e de crise das democracias representativas. Esse contexto acabou levando a uma percepção comum de uma crise de accountability em todas as democracias. Sendo que foi a partir destes fatores inter-relacionados que se passou a defender uma nova agenda para o accountability.

Voltando à análise do conceito de accountability social, Peruzzotti e Smulovitz (2002), Insunza e Gurza (2010) e Hernandez Quinõnes (201I) lecionam que a accountability evidencia um padrão de relação entre diferentes representações do estado e da sociedade. Enquanto na accountability tradicional (horizontal e vertical) essa relação se estabelece em torno de um Principal (Sociedade) e um Agente (Estado), na accountability social as relações estabelecidas são múltiplas, incorporando vários atores ao processo e redefinindo o âmbito de relações existente entre agente e principal. Daí o potencial da governança democrática em promover tanto uma reflexão sobre os novos aportes teóricos de accountability, quando em termos de ação coletiva que auxilia na redefinição de sua perspectiva tradicional. Para Insunza e Gurza (2010) e Hernandez Quinõnes (2011), o mapa conceitual com as múltiplas interações da accountability seria assim esquematizado:

Figura 4 - Accountability em perspectiva relacional 


\section{ACCOUNTABILITY RELACIONAL}

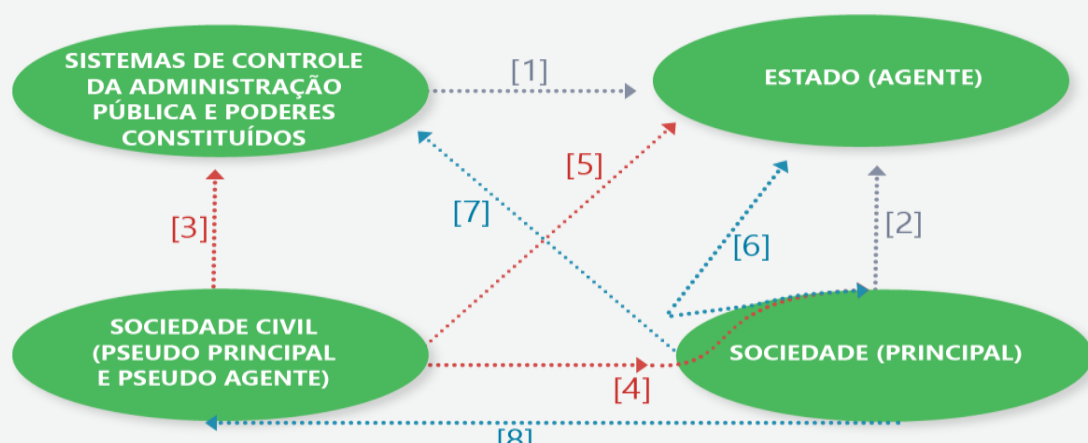

[8]

[1] Accountability Horizontal

[2] Accountability Vertical

[3] Accountability Social Pró-Horizontal

[4] Accountability Social Pró-Vertical (Eleitoral)
[5] Accountability Social Transversal

[6] Accountability Cidadã Transversal

[7] Accountability Cidadã Pró-Horizontal

[8] Accountability Social Cidadã

Fonte: Adaptado de Insunza e Gurza (2010)

Insunza e Gurza (2010) alertam que esta esquematização representa uma simplificação a partir de suas constatações de pesquisa, representando modelos ideais, tendo apenas o objetivo de sintetizar o universo relacional em termos de accountability no continente latino-americano. A seguir é apresentado quadro síntese conceitual de cada abordagem:

Quadro I - Qualificativos de accountability

\begin{tabular}{|c|l|}
\hline $\begin{array}{c}\text { Qualificação de } \\
\text { Accountability }\end{array}$ & \multicolumn{1}{|c|}{ Considerações e explicações a partir de Hernandez Quinõnes (201r): } \\
\hline & $\begin{array}{l}\text { A partir do trabalho de O’Donnel (1998). Representa os mecanismos de } \\
\text { interação e fiscalização mútua entre os poderes constituídos e outras } \\
\text { agências governamentais, principalmente as de controle. Tem como } \\
\text { lógica a ideia de freios e contrapesos (Checks and Balances) entre os } \\
\text { órgãos governamentais. A interação e a fiscalização é assegurada a } \\
\text { partir de regras e normas que visam garantir a estabilidade do sistema } \\
\text { democrático. }\end{array}$ \\
$\begin{array}{c}\text { Accountability } \\
\text { Horizontal }\end{array}$ \\
\hline $\begin{array}{c}\text { Accountability } \\
\text { Vertical }\end{array}$ & $\begin{array}{l}\text { A partir do trabalho de O’Donnel (1998). Representa a expressão da } \\
\text { soberania popular mediante o voto. Os cidadãos controlam os } \\
\text { governantes mediante o processo eleitoral de forma ascendente. Ainda }\end{array}$ \\
\hline
\end{tabular}




\begin{tabular}{|c|c|}
\hline & $\begin{array}{l}\text { interferem nesse processo as dinâmicas de controle social e da mídia, } \\
\text { exercendo controle sobre as agências estatais e os mecanismos de } \\
\text { accountability horizontal. }\end{array}$ \\
\hline $\begin{array}{l}\quad[3] \\
\text { Accountability } \\
\text { Social Pró- } \\
\text { Horizontal }\end{array}$ & $\begin{array}{l}\text { A partir dos trabalhos de Perruzzotti e Smulovitz (2002). Neste } \\
\text { mecanismo, as agências governamentais são impulsionadas por atores } \\
\text { coletivos, organizações da sociedade civil, redes sociais, movimentos } \\
\text { sociais e meios de comunicação. A relação se estabelece entre atores } \\
\text { organizados e coletivos com as agências do estado. Incluem as } \\
\text { diferentes expressões de mobilização cidadã, escândalos expostos pela } \\
\text { mídia, ações de pressão daquelas instâncias para assegurar o acesso à } \\
\text { informação. O objetivo é impulsionar o funcionamento das agências } \\
\text { estatais de controle com a finalidade de impor sanções e exercer } \\
\text { controle sobre elas no que se refere à implementação de políticas } \\
\text { públicas e a prestação de serviços públicos; }\end{array}$ \\
\hline $\begin{array}{c}{[4]} \\
\text { Accountability } \\
\text { Social Pró- } \\
\text { Vertical } \\
\text { (Eleitoral) }\end{array}$ & $\begin{array}{l}\text { A partir do trabalho de Ackermann (2004). Fazem referência às } \\
\text { iniciativas e ações de controle impulsionadas por atores coletivos da } \\
\text { sociedade, redes e aliança de organizações sociais e meios de } \\
\text { comunicação que visam influenciar no conjunto da sociedade a } \\
\text { qualificação do voto. Realizam controle e supervisão sobre assuntos e } \\
\text { políticas específicas como a transparência eleitoral, a luta contra a } \\
\text { corrupção, o monitoramento e avaliação de políticas sociais, entre } \\
\text { outros. Buscam impactar não somente na ativação dos dispositivos de } \\
\text { pesos e contrapesos, como aspiram garantir os direitos a cidadania, um } \\
\text { melhor acesso à informação pública, impactar a formação da opinião } \\
\text { pública com o propósito de que se possa qualificar a cidadania para } \\
\text { avaliar o desempenho de resultados das diferentes políticas conduzidas } \\
\text { pelo Estado. }\end{array}$ \\
\hline $\begin{array}{l}\quad[5] \\
\text { Accountability } \\
\text { Diagonal ou } \\
\text { Transversal }\end{array}$ & $\begin{array}{l}\text { A partir do trabalho de Goetz e Jenkins (20oI), Insunza (2002) e } \\
\text { Insunza e Gurza (20Io). Se refere a atores coletivos que impulsionam o } \\
\text { exercício do controle, a vigilância, o monitoramento e a sanção sobre } \\
\text { políticos, funcionários públicos e empresas. É representada por atores } \\
\text { coletivos que se concebem como representantes da sociedade, } \\
\text { conselhos e comitês de avaliação de políticas públicas, mas que podem } \\
\text { ser levados à frente também por cidadãos individuais. Por um lado } \\
\text { podem ser instituições do próprio aparato estatal, criadas para } \\
\text { fomentar a participação cidadã, focada no controle e na cogestão das } \\
\text { políticas públicas. Por outro lado, são espaços institucionais de caráter } \\
\text { deliberativo com poderes e faculdades para exigir e impor decisões aos } \\
\text { atores estatais sujeitos ao controle. }\end{array}$ \\
\hline $\begin{array}{l}{[6]} \\
\text { Accountability } \\
\text { Cidadã } \\
\text { Diagonal }\end{array}$ & $\begin{array}{l}\text { A partir do trabalho de Insunza e Gurza (20Io). São iniciativas de } \\
\text { controle político e de funcionários do espaço institucional, } \\
\text { impulsionadas por cidadãos, a título pessoal, sem buscar uma aspiração } \\
\text { ou necessidade de representação. Utilizam de ferramentas judiciais, } \\
\text { petições públicas, interpondo queixas e denúncias, baseando-se em } \\
\text { direitos constitucionais e legais. }\end{array}$ \\
\hline
\end{tabular}


[7]

Accountability

Cidadã Pró-

Horizontal

A partir do trabalho de Insunza e Gurza (2010). Representam iniciativas que partem da Sociedade para as agências de governo (Controladorias, Ouvidorias, Poder Judiciário, etc.) que interpõem reclamações, queixas e denúncias em defesa dos direitos individuais, de grupos de interesse ou de interesse público;

Baseado no trabalho de Insunza e Gurza (2010), Peruzzotti e Smulovitz (2002), Peruzzotti (2012), entre outros trabalhados nesta secção. Tratase de um esforço de síntese envolvendo a discussão desta secção: Esta

[8]

Accountability perspectiva reúne diversos atores da sociedade civil interagindo com as Social Cidadã dinâmicas e as regras do jogo democrático, objetivando fortalecer as instituições democráticas, apontando suas fragilidades e limitações, valorizando a cidadania ativa e propositiva que surge no contexto de uma sociedade civil que reúne uma pluralidade de atores em ação coletiva. O objetivo final é o resgate da dimensão política da cidadania.

Fonte: elaborado pelo autor a partir de Abrucio e Loureiro (2005), Hernandez Quinõnes (2011), Insunza e Gurza (2010), Peruzzotti e Smulovitz (2002), Peruzzotti (2012).

Hernandez Quinõnes (2011), adotando a perspectiva relacional de accountability, interpreta o conceito de social accountability como as práticas e os dispositivos de controle social vertical não-eleitoral de políticos, funcionários e empresas que são, por um lado, impulsionados pela cidadania e, por outro, práticas e dispositivos de controle transversal direcionados, também pela cidadania, para os diferentes mecanismos institucionais e de controle, criados pelo próprio Estado. Em síntese, enquanto as perspectivas [I], [2], [6] e [7] utilizam e estão relacionadas ao acionamento das instituições democráticas, via suas regras institucionais, as perspectivas [3], [4], [5] e [8] apresentam inovação em seus processos de acionamento, não necessariamente usando mecanismos e regras institucionais formatadas. Novos instrumentos de controle social e de pressão podem ser criados e levados em consideração nesse processo de interação institucional.

Por fim, as diversas inovações cívicas e democráticas ocorridas no contexto latinoamericano (ISUNZA e GURZA, 2ог; HERNANDEZ QUINÕNES, 2ог; PERUZZOTTI e SMULOVITZ, 2002; PERUZZOTTI, 2012); e brasileiro (DOIN et al., 2012; ROCHA et al., 2012) representariam algumas das evidências sobre o surgimento destas novas qualificações, permitindo outras possibilidades analíticas para a interpretação da prática da accountability (DENHARDT e DENHARDT, 2007; DENHARDT, 2012; BEVIR, 2oII; HERNANDEZ QUINÕNES, 2oII; ROCHA, 2oII; ROCHA et al., 2012). 
Sob esta lógica de ampliação da visão geométrica da accountability, em perspectiva relacional, construída a partir da interação entre uma pluralidade de atores e abordagens, se torna central o entendimento do processo de governança democrática, envolvendo diferentes instituições e atores da sociedade. Denhardt (p. 275, 2012) leciona que o processo de governança coloca em evidência questões relevantes para o futuro das normas e instituições democráticas. Se por um lado, observa-se que as redes de governança operam fora dos mecanismos normais de controle e accountability democráticos. Por outro, pode-se verificar que elas aproximam cidadãos engajados nas discussões de política pública e nas questões de implementação.

Bevir (20II), ao trabalhar sua genealogia do conceito de governança democrática, destaca que as novas teorias da governança também encontram-se relacionadas a novas abordagens sobre a democracia e accountability. Assim, a accountability procedimental, típica das estruturas hierárquicas dos governos burocráticos, característica da Velha Administração Pública (DENHARDT e DENHARDT, 2007; DENHARDT, 2012, ROCHA, 20II) perspectivas [I], [2], [6] e [7] de Insunza e Gurza (2010) -, abre espaço para outras formas de os governos serem responsabilizados no processo político e corresponderem às expectativas da sociedade (HEIDEMANN, 2009) - perspectivas [3], [4], [5] e [8] de Insunza e Gurza (2010).

Na perspectiva da Nova Gestão Pública, dos mercados e das redes, Bevir (20II) leciona sobre a existência de uma accountability por desempenho que traz consigo uma dimensão de resultados e performance dos governos - perspectivas [6] e [7] de Insunza e Gurza (2010), que não deixa totalmente de lado a preocupação com a formalidade dos procedimentos, evidenciando perspectivas da Velha Administração Pública (DENHARDT e DENHARDT, 2007; DENHARDT, 2012, ROCHA, 2011).

Bevir (2010) também aponta, nesse sentido, para uma visão multifacetada de accountability. Ele não a denomina de social accountability. Denhardt e Denhardt (2007) e Denhardt (2012) falam em desafios para as instituições democráticas e para a accountability no que se refere aos processos de governança e participação. Porém, os três autores, embora teorizem sobre as características de uma accountability multifacetada, não a qualificam como social, nem este era seu objetivo. Entretanto, tendo em vista as características 
indicadas por eles, partiu-se do pressuposto que, a accountability social possa expressar a característica multifacetada defendida pelos autores.

\section{Ação Coletiva, Accountability Social e Governança: o Modelo de Análise.}

Tendo em vista o referencial conceitual adotado para este trabalho - ação coletiva, governança democrática e a accountability social -, o ponto de partida para a construção do modelo teórico foi a ação coletiva, por meio da teoria da mobilização política. Como visto anteriormente, a teoria estrutura-se a partir do conceito de confronto político. Partindo-se desta categoria analítica, que destaca o surgimento de ações coletivas a partir de oportunidades e restrições políticas, específicas de um contexto social, percebeu-se sua aplicabilidade para a análise teórico-empírica das experiências selecionadas.

Da mesma forma, as categorias que compõem o confronto político expressas por Tarrow (2009) - forma, repertório e mobilização de estruturas - quando da prévia coleta de dados sobre as experiências e com a visita a campo, consolidaram-se como possibilidade de modelo de análise. A categoria da forma indica o modo pelo qual a ação coletiva opera para fazer sua causa ouvida no espaço público, sendo característica do contexto (GOHN, 20Io) e da própria estrutura de oportunidades e restrições políticas (TARROW, 2009). Os repertórios, representando as bandeiras da ação coletiva, apontavam no sentido da existência de um discurso comum às iniciativas e a sua conexão com redes de mesmo repertório - cidades justas, democráticas e sustentáveis - na América Latina. Por fim, tais ações mobilizam recursos financeiros, técnicos e políticos para alcançar ou traduzir em ação seu repertório, além de mobilizar as estruturas de governança já existentes neste mesmo processo.

Outro ponto que justifica a escolha por esta teoria remete às conclusões de Tarrow (2009) de que uma ação coletiva sustentada é capaz de gerar ciclos de confronto que, por sua vez, podem gerar confrontos transnacionais a partir do surgimento de redes. Essas conclusões de Tarrow (2009), aliadas à perspectiva do surgimento de uma sociedade civil global (COHEN, 2003) permitiram estabelecer as conexões necessárias para o desenvolvimento do modelo teórico que subsidiou a análise. 
As experiências colombianas, como visto, foram pioneiras na América Latina. Seu projeto político de tornar as cidades mais justas, democráticas e sustentáveis aponta com frequência o objetivo de incidir em políticas públicas, na agenda governamental e no aparato institucional da administração pública. Para alcançar esse objetivo, as iniciativas colocam em evidência a necessidade de informação qualificada, produzida e sistematizada pela sociedade civil, para o monitoramento dos governos locais. Transparência, prestação de contas e incentivo a sanções sociais e culturais reforçam a ação política destas iniciativas.

Assim, ao buscar incidência, as experiências ativam o sistema de accountability a partir das diferentes lógicas de relação expressas na Figura 4 - Esquema de accountability em perspectiva relacional. A governança existente na cidade, ao mesmo tempo em que é um meio no qual estas inciativas transitam, também é um fim almejado por estas iniciativas quando buscam qualificar o próprio sistema de governança e incidir na agenda da cidade.

É a partir desta reflexão que, para os efeitos deste modelo teórico, as iniciativas são vistas como uma das instâncias de governança local, chamando a atenção para um repertório que corresponde a um projeto político que dissemina a ideia de cidades mais justas, democráticas e sustentáveis. Essa estrutura de governança mobiliza e é mobilizada por recursos pessoais, financeiros e políticos em torno daquele repertório, acionando e ativando as diferentes modalidades de accountability, evidenciando uma perspectiva social do conceito. O resultado esperado, é a incidência em vários âmbitos: nas práticas de transparência pública e accountability, nas formas de participação cidadã, nas políticas públicas e na própria governança local.

Em linhas gerais, o modelo teórico desenvolvido esquematiza a seguinte argumentação analítica: as iniciativas das redes de cidades desenvolvem-se no contexto latino-americano a partir das estruturas de oportunidades e restrições políticas e das especificidades do contexto de cada cidade. Estes contextos entram em interação pelo confronto transnacional. O que norteia a ação destas experiências é a percepção de um projeto excludente de cidade, que estas inciativas visam confrontar, para construir cidades sustentáveis. Este último representa um conjunto de valores e práticas, os repertórios, que 
são adotados pelos atores em ação coletiva, que assumem uma forma característica, mobilizando estruturas locais, nacionais e transnacionais na estrutura do confronto, visando gerar efeitos de curto e longo prazo, aqui interpretados como incidência, sobre a governança local e sobre o sistema de accountability.

A figura 5, a seguir, esquematiza a estrutura de análise.

Figura 5 - Esquema Modelo de Análise

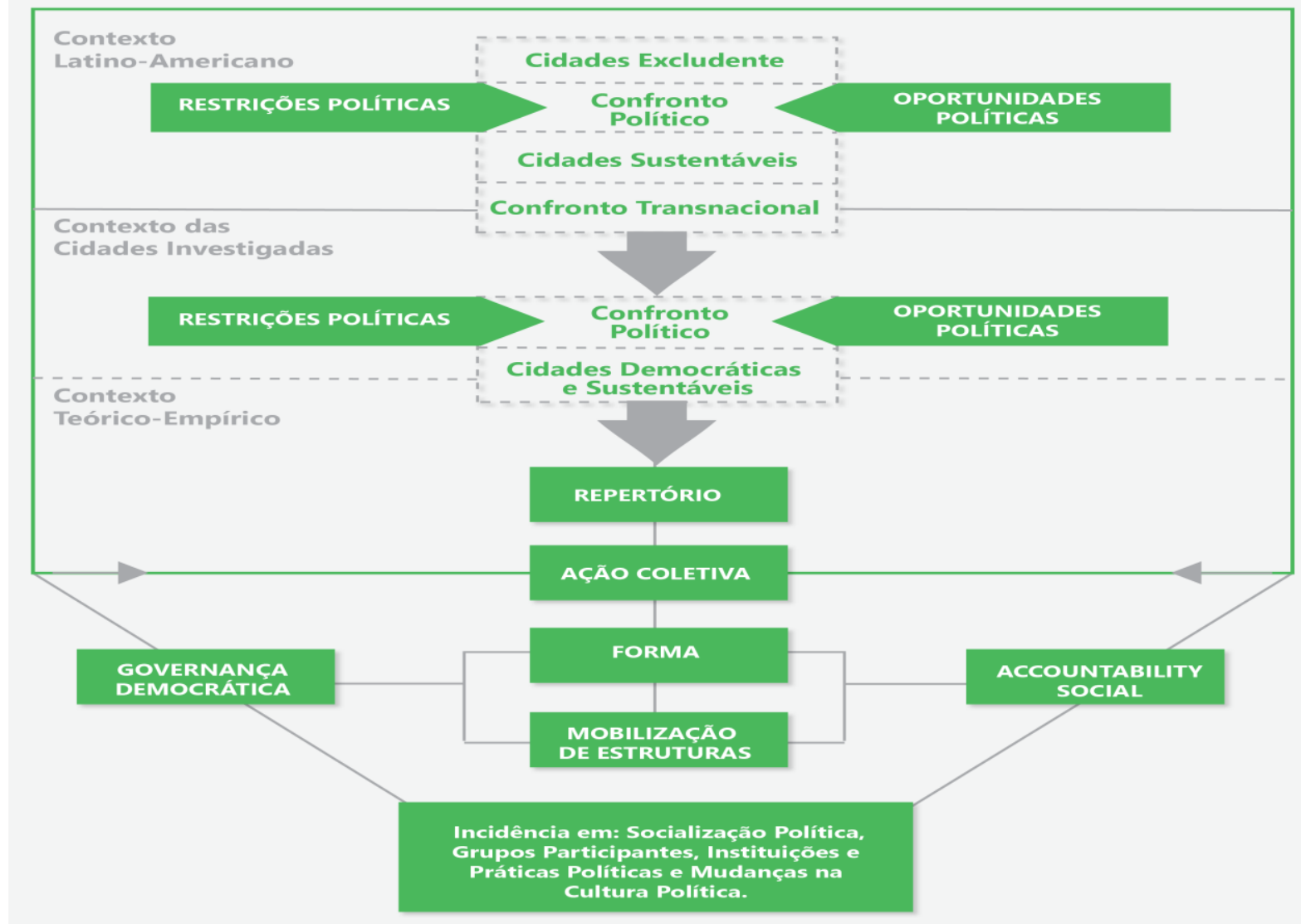

Fonte: elaborado pelo autor com base no referencial conceitual.

Para Tarrow (2009) há três efeitos de longo prazo e indiretos quando uma ação coletiva é desencadeada: (i) Socialização Política e dos Grupos Participantes; (ii) Instituições e Práticas Políticas; e, (iii) Cultura Política. Tendo em vista a construção do modelo de análise estrutura-se a partir da categoria analítica da ação coletiva, considerouse para os efeitos do modelo, estes três efeitos como incidência. Da mesma forma, a incidência se processa sobre a governança e o sistema de accountability na medida em que as 
instituições e as práticas políticas são influenciadas ou impactadas pelo padrão de ação coletiva destas redes.

No que se refere a forma de ação coletiva, tendo em vista o modelo de análise, na perspectiva de Tarrow (2009), pode-se afirmar que são ações coletivas que buscam a convenção em termos do repertório que disseminam, o que é compatível com o conceito de governança democrática. Entretanto, isso não quer dizer que não existam conflitos na relação estabelecida entre estas instâncias.

É importante salientar que o recorte da análise não aprofundou o contexto de restrições e oportunidades políticas do continente latino-americano, restringindo-se apenas a destacar e generalizar discussões que envolvem o surgimento destas redes no continente latino-americano e como suas ações repercutem em escala continental, gerando ações coletivas locais e articuladas em rede em nível transnacional. A análise foca-se essencialmente sobre o contexto das cidades investigadas a partir do recorte analítico apresentado.

Há que se destacar também que o modelo de análise e sua representação na Figura 5 representam, de certa forma, um resultado da própria pesquisa, uma vez que a construção deste trabalho usou a perspectiva de delineamento de pesquisa de Deslauriers e Kérisit (2008), em que as convergências e divergências entre teoria, campo e resultados obtidos são construídos conjuntamente, não adotando uma linearidade estrita.

\section{Análise dos Casos}

O quadro a seguir sintetiza as principais conclusões, nas três cidades, no que se refere à restrições e oportunidades políticas e a mobilização de estruturas. A partir da síntese é traçado um breve panorama de que como se estrutura a ação local das iniciativas, projetos e ações desenvolvidos, como surgiram, se articulam, etc. $\mathrm{Na}$ sequência são apresentados considerações e reflexões gerais sobre as três iniciativas. 


\begin{tabular}{|c|c|c|}
\hline Cidade & Restrições e Oportunidades Políticas & Mobilização de Estruturas \\
\hline 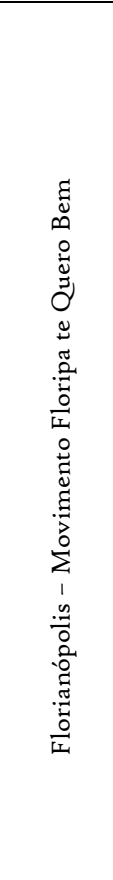 & $\begin{array}{l}\text { Restrições } \\
\text { - Colocadas em evidência a partir do debate iniciado pelo Floripa te Quero Bem: Saúde, Educação, Segurança, Mobilidade, } \\
\text { Planejamento Urbano. } \\
\text { - Outros pontos: Saneamento Básico; Crescimento Populacional (Qualidade de Vida e Oportunidades de Trabalho } \\
\text { promovendo migração); } \\
\text { - Várias organizaçôes com interesses semelhantes e projetos em potencial. Entretanto, trabalhando separadamente e com } \\
\text { dificuldades de encontrar pontos de convergência em termos de ação sobre à cidade. } \\
\text { Oportunidades } \\
\text { - A consolidação da Rede brasileira e latino-americana de cidades; } \\
\text { - Influência e reconhecimento do trabalho da Rede Nossa São Paulo, com a realização do primeiro Plano de Metas, } \\
\text { inspirando outras cidades; } \\
\text { - As Cartas Compromisso disseminadas pela Plataforma Cidades Sustentáveis, com Prefeitos e Prefeituras no ano } \\
\text { eleitoral; } \\
\text { - Os dois candidatos que estavam na liderança do pleito trouxeram, em seus projetos de governo, componentes } \\
\text { relacionados a uma preocupação com a cidade. São eles: "Uma Florianópolis ainda Melhor" e "Por Uma Cidade Mais } \\
\text { Humana". Esse último, era do candidato e atual Prefeito de Florianópolis, que apresentou o Plano de Metas. } \\
\text { Fato Catalisador } \\
\text { Reaçãa à entrevista de Guga Kuerten (ex-tenista brasileiro) a um programa de esportes do Grupo RBS, quando levantou a } \\
\text { possibilidade de deixar a cidade devido à redução da qualidade de vida. A declaração levou a organização do Painel RBS, } \\
\text { debatendo o futuro da cidade. Após o painel um grupo de quatro instituiçôes - Instituto Comunitário da Grande } \\
\text { Florianópolis, Instituto Guga Kuerten, Instituto Pe. Vilson Groh e Grupo RBS - constituem um grupo de trabalho que } \\
\text { articula 6o organizações e 8o especialistas na discussão de desafios para a cidade. A mobilização culminou no documento } \\
\text { "Desafios por Florianópolis", que subsidiou a elaboração do Plano de Metas da cidade. }\end{array}$ & 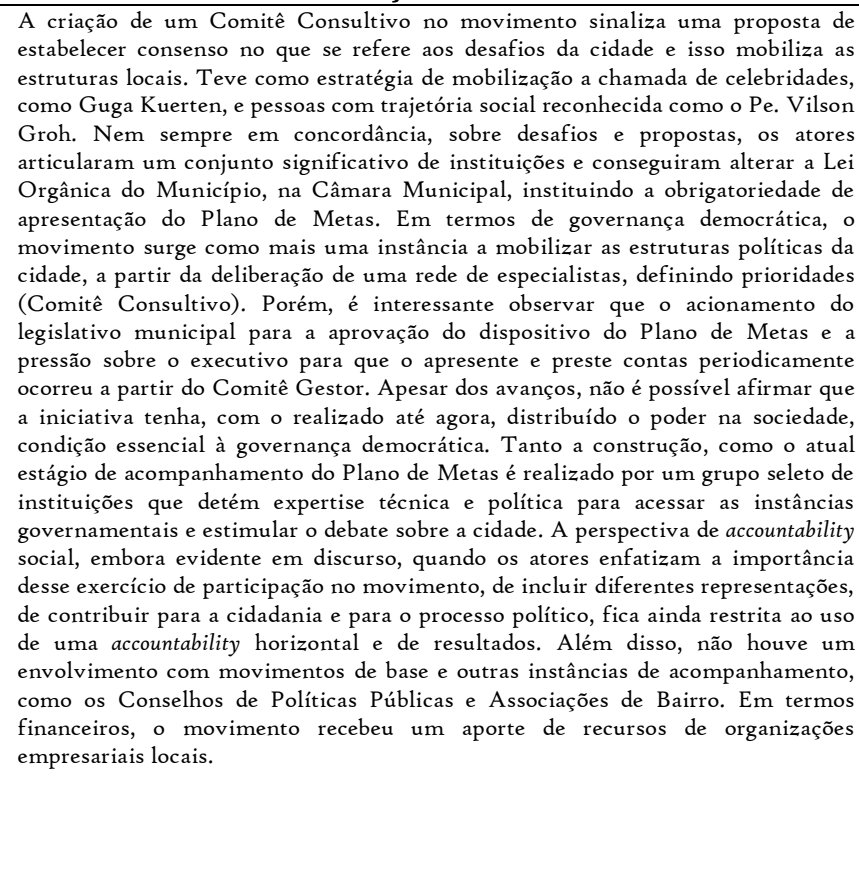 \\
\hline
\end{tabular}




\begin{tabular}{|c|c|c|}
\hline 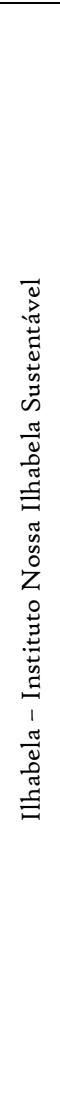 & $\begin{array}{l}\text { Restrições } \\
\text { - Saneamento Ambiental Comprometido; } \\
\text { - Degradação da qualidade de vida por vários fatores (segurança, falta de moradias, migração, mobilidade } \\
\text { urbana, etc); } \\
\text { - Pertencimento à Cidade - muitas pessoas que vêm de fora atraídas pela qualidade vida que não } \\
\text { demonstram interesse pela cidade - vem para descansar - e também os 'nativos' que entram em conflito com } \\
\text { quem vem de fora. } \\
\text { - Sazonalidade Turística - problemas de infraestrutura urbana como mobilidade são atenuados no período de } \\
\text { Dezembro até Março; } \\
\text { - Porto de São Sebastião - Perspectiva de ampliação e transformação do canal em corredor de exportação e os } \\
\text { receios com os impactos gerados com isso; } \\
\text { Oportunidades } \\
\text { - A oportunidade em maior evidência, para o desencadear da iniciativa, foi as relações pessoais com uma das } \\
\text { lideranças da Rede Social Brasileira e da proximidade com a cidade de São Paulo que, no mesmo período, } \\
\text { articulava a estruturação da Rede Nossa São Paulo. A participação de uma das lideranças na viagem a } \\
\text { Bogotá, para conhecer a experiência, demonstra o alinhamento com a proposta do Nossa São Paulo e o } \\
\text { modelo inspirador de Bogotá; } \\
\text { - O contexto de participação social da cidade, relatado pela maioria dos entrevistados como sendo um } \\
\text { diferencial em Ilhabela, em que há várias associaç̃̃es e organizações ativas em várias questões, percebendo- } \\
\text { se que isso poderia ser potencializado com o surgimento da iniciativa; } \\
\text { - A existência de uma estrutura turística engajada em preservar o patrimônio natural que existe na cidade. } \\
\text { Fato Catalisador } \\
\text { Rede de relacionamento pessoal e a percepção de que algo poderia ser feito para garantir a sustentabilidade } \\
\text { da cidade. A mobilização surge com um Manifesto de instituições locais pela qualidade de vida na cidade. } \\
\text { Surge como Movimento Nossa Ilha Mais Bela e institucionaliza-se em seis meses. }\end{array}$ & $\begin{array}{l}\text { O Instituto surge a partir do Movimento Nossa Ilha mais Bela. De } \\
\text { acordo com os entrevistados, a necessidade de uma liderança forte, com } \\
\text { apoio técnico e político levou a decisão de institucionalizar-se, para } \\
\text { fortalecer sua ação na cidade. A articulação e inserção do Instituto com } \\
\text { os Conselhos Municipais da Cidade, com as Associações de Bairro e } \\
\text { com outras organizações na realização de suas atividades evidencia um } \\
\text { engajamento maior entre as estruturas locais de governança e avanços } \\
\text { em relação a ela, quando comparados em relação a Florianópolis, onde } \\
\text { ainda não ocorre esse engajamento do movimento com os conselhos. } \\
\text { Apenas há um envolvimento direto das instituições, mas não enquanto } \\
\text { movimento. Seu relacionamento com órgãos estaduais e federais, na } \\
\text { busca de soluçães para os problemas da cidade, evidencia uma percep̧ão } \\
\text { pelo Instituto de que a solução de alguns dos problemas da cidade } \\
\text { dependem de outras esferas, além da municipal, como é o caso do } \\
\text { saneamento básico. A tensão com o executivo municipal aponta para } \\
\text { diferentes visões de cidade, representando um dos desafios para o } \\
\text { Instituto e para o processo de governança do qual faz parte, ao exercer } \\
\text { controle político sobre o governo local. Diferentes perspectivas de } \\
\text { accountability são verificadas, desde as formas tradicionais com seus } \\
\text { trabalhos de monitoramento da atividade legislativa, como os que } \\
\text { buscam influenciar os cidadãos, a sociedade e as instituições na } \\
\text { qualificação do processo eleitoral e no exercício do controle sobre a } \\
\text { atividade governamental. Seus projetos de conscientização cidadã } \\
\text { mobilizam outras organizações que trabalham com educação e teatro. } \\
\text { Os recursos financeiros mobilizados vem de doaçôes de empresários } \\
\text { locais, ligados ao setor de turismo local. São proprietários de pousadas e } \\
\text { hotéis. Também há projetos financiados pela Fundação Itaú e Fundação } \\
\text { Avina. }\end{array}$ \\
\hline
\end{tabular}




\begin{tabular}{|c|c|c|}
\hline 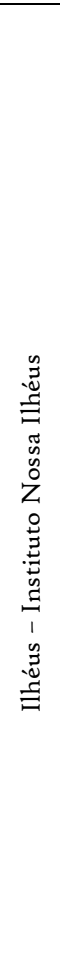 & $\begin{array}{l}\text { Restrições } \\
\text { - Cultura Política (Coronelismo, Paternalismo, Apadrinhamento) e seus reflexos sobre as instituições } \\
\text { políticas e a cidadania; } \\
\text { - A Crise do Cacau - Alteração em sua Base Econômica a partir dos anos de ıg6o; } \\
\text { - Baixos Índices Socioeconômicos; } \\
\text { - Baixa participação das pessoas e das instituições no processo político; } \\
\text { Oportunidades } \\
\text { - A disponibilidade de uma liderança local em articular a inciativa pela sua expertise técnica e política } \\
\text { oriunda da atuação em outras organizaçoes com finalidades correlatas; } \\
\text { - A existência de organizações com expertises distintas voltadas ao desenvolvimento da cidade em diferentes } \\
\text { áreas e que já vinham trabalhando algo nesse sentido; } \\
\text { - O Fortalecimento da Rede Social Brasileira por Cidades Justas, Democráticas e Sustentáveis - } \\
\text { disseminação de seu repertório e metodologias de ação, bem como o trabalho da Rede Nossa São Paulo, } \\
\text { servindo como referência no país para que pessoas e instituições pudessem iniciar esse processo de reflexão } \\
\text { sobre as cidades; } \\
\text { Fato Catalisador } \\
\text { Preocupação com os impactos do Complexo Intermodal do Porto Sul. Liderados por Maria do Socorro } \\
\text { Mendonça e pelo Teatro Popular de Ilhéus, um grupo de instituições apoia a constituição do Instituto com a } \\
\text { realização de um estudo, construído a partir de reuniões lúdicas nas comunidades da cidade, chamado a } \\
\text { Ilhéus que Queremos, debatendo os indicadores da cidade e a situação que se gostaria de alcançar, a Ilhéus do } \\
\text { Futuro. }\end{array}$ & $\begin{array}{l}\text { Foi possível identificar uma articulação local já estabelecida } \\
\text { antes do Instituto, que com sua ação passou a exercer mais } \\
\text { fortemente esse trabalho de articulação. Embora existisse uma } \\
\text { governança local, com instituições isoladamente lutando por } \\
\text { melhorias para a cidade, é evidente a participação de grupos } \\
\text { mais representativos da cidade como o Sebrae, Associação de } \\
\text { Turismo e Trade Turístico. Há um envolvimento com } \\
\text { movimentos de base mais comunitária, como o Teatro Popular } \\
\text { de Ilhéus, importante parceiro do Instituto no que se refere a } \\
\text { formação para a cidadania. É interessante observar que a } \\
\text { governança local é catalisada pelo Instituo e sua liderança. Há } \\
\text { um acionamento de instâncias governamentais em órgão } \\
\text { estaduais e federais na frente de trabalhos dos Planos } \\
\text { Municipais da Mata Atlântica. Há um projeto específico de } \\
\text { acompanhamento do legislativo municipal, apresentando dados } \\
\text { sobre a qualidade da produção legislativa, presença em sessões } \\
\text { da câmara e acompanhamento de contratos e licitações. } \\
\text { Programa que gera constrangimento às autoridades locais e } \\
\text { relaciona-se ao contexto de accountability. Com o Teatro Popular } \\
\text { de Ilhéus e um programa de rádio semanal, o Instituto trabalha } \\
\text { temas voltados à conscientização da população sobre a realidade } \\
\text { da cidade a partir de seus indicadores sociais. No que se refere } \\
\text { ao financiamento, o instituto recebe aporte de recursos do } \\
\text { Instituto Arapyau - organização voltada ao aporte de recursos } \\
\text { financeiros e de articulação entre organizações e lideranças que } \\
\text { trabalham com a promoção da sustentabilidade. }\end{array}$ \\
\hline
\end{tabular}


A partir da síntese apresentada no quadro acima, nos três casos investigados, o contexto de restrições e oportunidades políticas que desencadeou o processo de confronto político teve fatos emblemáticos, aliados à oportunidades específicas de cada contexto, que colocaram em evidência uma preocupação com o futuro da cidade.

Com exceção de Ilhabela, as iniciativas receberam a influência do repertório da rede brasileira no decorrer de sua estruturação. Em Florianópolis e Ilhéus, as lideranças destacaram à existência de um relacionamento prévio com membros da própria Rede e demais experiências que a compõem, como é o caso da Rede Nossa São Paulo. Porém, a influência do repertório chegou quando as inciativas já estavam mais organizadas. Assim, fica evidente que contexto de restrições e oportunidades políticas não desencadeia diretamente o surgimento das iniciativas. Elas são influenciadas por pessoas ou grupos que pela sua rede de relações e conhecimento sobre as redes nacional e internacional desencadeiam o processo da ação coletiva e, passam então, a chamar a atenção para aquele contexto de restrições e oportunidades políticas vivenciado por cada cidade.

A influência da rede brasileira também foi perceptível, nos três casos, em relação ao compartilhamento de práticas, metodologias e atividades enquanto as iniciativas se estruturavam. O repertório foi evidenciado na fala dos atores com bastante semelhança em relação aos valores de justiça, democracia e sustentabilidade apregoados. Os próprios projetos e ações desenvolvidos em âmbito local reforçam esse quadro de valores. Comum às três iniciativas foi o desenvolvimento dos Planos de Metas - instrumentos de acompanhamento da gestão pública por indicadores -, incialmente realizado, no Brasil, pela Rede Nossa São Paulo. Em cada uma das cidades investigadas, a implementação e os efeitos do Plano de Metas foram diferentes. Em Ilhéus, por exemplo, o instrumento começou a ser articulado pela Ação Ilhéus e não pelo Instituto Nossa Ilhéus, que posteriormente assumiu o trabalho.

As similitudes em termos de restrições políticas, relatadas pelos entrevistados, em linhas gerais, apontam no sentido dos problemas comuns 
enfrentados hoje pelas três cidades como o crescimento populacional, a migração, a falta de moradias, o aumento da violência, a falta de oportunidade de trabalho e geração de renda, a mobilidade urbana, saneamento básico, degradação ambiental, desenvolvimento sustentável do turismo local etc. Esse quadro de restrições é comum às cidades latino-americanas, inclusive as pequenas e médias, representando um desafio para iniciativas como estas. Ainda em relação às similitudes, os fatos desencadeadores evidenciam tais problemas e a ameaça ao seu agravamento. Em Ilhabela e Florianópolis, a qualidade de vida foi relatada como um dos fatores centrais para a migração de pessoas. Sem necessariamente deter os equipamentos urbanos adequados e suficientes para absorver todo esse contingente, a qualidade de vida no futuro estava ameaçada. Já em Ilhéus, essa migração é vivenciada a partir da crise da monocultura do cacau entre os anos de 1980 e 1990. As pessoas procuram a cidade em busca de oportunidades, deixando o meio rural que a circunda.

Nas três cidades, a questão turística como uma dimensão importante do pensar e agir sobre a cidade e da promoção do seu desenvolvimento é evidenciada. Entretanto, em Florianópolis, os desafios propostos pelo Floripa Te Quero Bem não destacaram a questão do turismo com grande amplitude, o que ocorre nas outras duas cidades. As metas propostas pela Prefeitura de Florianópolis são apresentadas mais em termos de infraestrutura para atender ao turista e chamar mais pessoas para a cidade do que propriamente como uma questão ligada ao contexto que faria dela uma cidade sustentável.

Com relação as pessoas $e$ as instituições envolvidas no processo de ação coletiva, nas cidades analisadas se evidenciou que elas detêm conhecimento prévio sobre questões relacionadas à cidade. São atores que já participavam ou ainda participam de iniciativas da sociedade civil e que já têm uma expertise técnica e política que potencializa a mobilização das estruturas locais em torno das quais a ação coletiva se sustenta e viabiliza. Nas três cidades, os grupos de atores são distintos, embora homogêneos. Destacam-se grupos ligados ao setor empresarial e suas entidades de classe, ao setor de turismo, à construção civil, ao ramo imobiliário, ao 
setor social. São organizações que conhecem o espaço político da cidade e acabam se unindo às iniciativas seja com apoio político, técnico ou financeiro. Além disso, as iniciativas estão articuladas a outras redes locais, nacionais e transnacionais que também congregam esse mesmo tipo de atores e interesses.

Com relação às lideranças, em Ilhéus, se sobressai a figura de uma líder local. Em Ilhabela, as lideranças vêm de uma trajetória em organizações da sociedade civil ligadas ao meio-ambiente. Em Florianópolis, um grupo de mídia coloca em evidência a discussão sobre os desafios da cidade, articulando-se à instituições comunitárias já respaldadas técnica e politicamente pelo seu trabalho na cidade.

Em relação às pessoas, um fator que chama a atenção é que em Florianópolis muitos dos envolvidos com o movimento não são da cidade. Por exemplo, uma das lideranças que auxiliou no desenho da iniciativa em Florianópolis, do Grupo RBS, ligado à organização Globo, não é natural da cidade. Em Ilhabela, o Presidente do Instituto é natural da cidade de São Paulo e envolveuse com a iniciativa após mudar-se para a cidade. Em Ilhéus, uma das lideranças também não é natural da cidade, mas alia-se a uma forte liderança local que idealizou a iniciativa. São pessoas de fora, trazendo suas experiências e imprimindo a sua visão sobre as potencialidades de cada cidade, bem como sobre os seus problemas. Um processo que nem sempre é facilitado. Em Ilhabela, foram relatados casos de perseguição política às lideranças do Instituto e questionamentos feitos pelos "nativos" sobre a legitimidade que alguém de "fora da cidade" teria para contribuir com ela.

Com relação à homogeneidade nos grupos que compõem as iniciativas, remete-se às considerações de Cefaï (2007) e Gohn (2010) sobre o paradigma racionalista da ação coletiva - o qual influencia a teoria da mobilização política -, que destacam que muitas iniciativas emergem de uma elite de empreendedores dispostos a investir em uma causa. Analisando a constituição do Movimento Floripa Te Quero Bem é perceptível a liderança do Comitê Gestor na condução dos trabalhos de articulação do Comitê Consultivo mais amplo, na elaboração dos 
eixos temáticos contemplados no relatório final do movimento e na condução dos trabalhos, dando sempre ênfase a uma dimensão técnica na sua condução e a uma escolha estratégica para o sucesso da iniciativa. Embora a decisão final fosse validada por meio de deliberação no Comitê Consultivo ampliado, a coordenação dos trabalhos esteve, no decorrer do processo, centralizada na figura das quatro organizações gestoras.

Em Florianópolis, o discurso dos atores traz com frequência a preocupação com o desenvolvimento de um projeto de ação objetivo e focado em suas escolhas, típico do paradigma racionalista e da teoria. Isso fica bastante evidente na opção de a iniciativa focar-se apenas na questão do Plano de Metas e nas atividades decorrentes dele - monitoramento dos indicadores, atualização periódica dos desafios e dos indicadores, apresentação de resultados periodicamente e na exigência de que a Prefeitura execute as ações propostas. Esses objetivos são claramente pontuados pelos atores e nos materiais disponíveis pelo movimento. Isso, em certa medida, reflete também sua fase inicial, em que muitos dos objetivos ainda estão em construção e amadurecimento.

O questionamento que fica em relação a Florianópolis, tendo em vista o trabalho, mais amplo e diverso, realizado/percebido em Ilhéus e Ilhabela, é o seguinte: em que medida apenas esta ação reflete o pensar uma cidade justa, democrática e sustentável? E até que ponto ela está envolvendo os atores da sociedade civil para além da discussão do Plano de Metas? Até que ponto não reforça apenas as formas mais tradicionais de governança da cidade e até mesmo dos mecanismos mais formais do sistema de accountability?

Em Ilhabela, ao analisar seu quadro de apoiadores institucionais e financeiros percebe-se a presença de organizações respaldadas politicamente e financeiramente. $O$ setor turístico surge como um importante articulador e financiador da experiência. A preocupação com dimensão técnica e formal também é evidente com o destaque dado à necessidade de institucionalização para garantir credibilidade, força política em relação ao que se propõem, possibilitar que pessoas capacitadas para a causa assumam responsabilidades específicas dentro dos projetos 
existentes, facilitar a captação de recursos e a condução da iniciativa como um todo, devido à dificuldade de conciliar diversos interesses.

A questão que fica para Ilhabela é até que ponto a participação e financiamento do setor turístico na inciativa será, no longo prazo, viável? Há interesses divergentes ligados a ampliação do setor imobiliário, atração de mais turistas e necessidades de novos equipamentos urbanos que, em certa medida, podem conflitar com os interesses em defesa da sustentabilidade ambiental defendida pela iniciativa. A linha entre apoio institucional e interesses é tênue.

Em Ilhéus, a liderança da presidente do Instituto é central para a compreensão do processo de mobilização da cidade e suas instituições. Ela vinha de uma trajetória em outra organização, a Ação Ilhéus, que já trabalhava assuntos relacionados à cidade. É a partir do seu conhecimento como uma pessoa que nasceu e viveu toda a sua vida em Ilhéus, ativando sua rede pessoal de relacionamento, que se promove a articulação das instituições e das pessoas interessadas em trabalhar pela causa do Instituto Nossa Ilhéus. O grupo de instituições mobilizado é representativo e já tem uma trajetória consolidada e uma expertise a oferecer.

Para Ilhéus, a reflexão é sobre identidade versus institucionalidade. É perceptível a capacidade de articulação, mobilização e até mesmo enfrentamento político à outras organizações e à Prefeitura feitas pela liderança. Existe um respeito muito grande a sua figura. Porém, a longo prazo, torna-se necessário que esse respeito e credibilidade sejam tão fortemente assimilados pelo Instituto, mais que pela liderança. Um dos entrevistados relata nesse sentido, que muitas pessoas desconhecem o Instituto, mas conhecem o trabalho da liderança.

Em linhas gerais, o questionamento que ficou é: até que ponto o processo de governança nestas cidades é realmente inclusivo ao ponto de representar os interesses de todos ou de um grupo particular de atores que detém essa expertise, reforçando a concentração de poder já existente e a tecnocracia? Mais especificamente em Ilhéus e Ilhabela, a partir de seus projetos de conscientização para a cidadania, há uma percepção dos atores de que é necessário o envolvimento dos cidadãos e a qualificação de sua avaliação e ação individual sobre a gestão 
pública. Os dois Institutos e o Movimento Floripa Te Quero Bem relatam a questão de não ser e não ter a pretensão de representar a sociedade civil da cidade, mas articular esse processo e demonstrar as possibilidades que o cidadão possui de transformar a realidade da cidade e a sua própria, assumindo ele seu papel de cidadão e não apenas de eleitor, principalmente tendo uma visão que integre o relacionamento entre as restrições enfrentadas e as soluções demandadas.

A tabela 2 a seguir compila, a partir da coleta de dados, as principais considerações sobre as três iniciativas no que se refere aos elementos constituintes da ação coletiva e da mobilização política:

\begin{tabular}{|c|c|}
\hline \multicolumn{2}{|c|}{ Síntese dos elementos de Ação Coletiva nas três Cidades } \\
\hline Elemento & Análise \\
\hline Institucionalização & $\begin{array}{l}\text { Em Ilhabela e Ilhéus as iniciativas optaram pela } \\
\text { institucionalização. Constituiu-se uma figura jurídica de } \\
\text { Instituto, com estruturas internas como Comitê } \\
\text { Deliberativo e Consultivo, representado por outras pessoas } \\
\text { e instituições. Em Florianópolis, há uma coordenação pelas } \\
\text { quatro organizações que compõem o Comitê Gestor e por } \\
\text { uma rede de outras organizações e especialistas. }\end{array}$ \\
\hline Motivação & $\begin{array}{l}\text { A intenção, o anseio de ter uma cidade melhor. Os atores } \\
\text { percebem o potencial de juntar expertises, projetos, } \\
\text { capacidades e conhecimento para consolidar e fortalecer a } \\
\text { ação em busca de cidades mais sustentáveis (conceito } \\
\text { amplo). }\end{array}$ \\
\hline Repertório & $\begin{array}{l}\text { As bandeiras do "justo", "democrático" e "sustentável" } \\
\text { estão presentes, tanto na fala dos atores como nos projetos } \\
\text { realizados, compartilhando metodologias com a rede } \\
\text { brasileira e latino-americana - Planos de Metas, o } \\
\text { Acompanhamento do Legislativo, os Projetos de } \\
\text { Conscientização Cidadã e Fortalecimento Democrático. } \\
\text { Percebe-se um pertencimento a este repertório, enquanto } \\
\text { quadro valorativo, reforçando a existência de um confronto } \\
\text { transnacional conectando as experiências na América } \\
\text { Latina. }\end{array}$ \\
\hline Forma & $\begin{array}{l}\text { A convenção é a forma principal de ação coletiva defendida, } \\
\text { não significando a inexistência de conflito na realização do } \\
\text { trabalho. A relação conflituosa entre o Instituto Ilhabela } \\
\text { Sustentável com a Prefeitura e a Sabesp, companhia de } \\
\text { saneamento do Estado de São Paulo serve de exemplo. }\end{array}$ \\
\hline Estruturas & Mobilizam ativos financeiros, pessoais e institucionais a \\
\hline
\end{tabular}




\begin{tabular}{|c|c|}
\hline Mobilizadas & $\begin{array}{l}\text { partir de suas redes de relacionamento. A expertise técnica } \\
\text { e política é central na mobilização promovida pelas } \\
\text { iniciativas. Instituições que já tem credibilidade e um } \\
\text { reconhecimento na cidade, destacam-se como participantes. } \\
\text { Utilizam-se do recurso das celebridades para chamar a } \\
\text { atenção do público sobre a causa, de grupos de mídia } \\
\text { fortalecidos e canais alternativos para chegar até as pessoas. } \\
\text { O processo de governança democrática é fortalecido } \\
\text { (expressa e influencia) a partir destas novas representações, } \\
\text { envolvendo diversas outras na ação, realizado e } \\
\text { articulando-se a mecanismos já existentes e ativando o } \\
\text { sistema de accountability. Desejam influenciar a agenda } \\
\text { governamental e a cidadania em torno do projeto do projeto } \\
\text { político da rede. }\end{array}$ \\
\hline Principais Sujeitos & $\begin{array}{l}\text { Há um conjunto relativamente homogêneo de atores. A } \\
\text { grande maioria ligada ao setor empresarial e entidades de } \\
\text { classe empresarial. Em Ilhabela, o setor de turismo engaja- } \\
\text { se fortemente com à inciativa. Nas três cidades, as } \\
\text { instituições apresentam semelhanças em termos de atuação } \\
\text { e trajetórias consolidadas, devido ao trabalho social que } \\
\text { realizam. }\end{array}$ \\
\hline $\begin{array}{c}\text { Estratégias e } \\
\text { Instrumentos } \\
\text { Utilizados }\end{array}$ & $\begin{array}{l}\text { Reuniões Consultivas/Deliberativas; Relatórios Técnicos } \\
\text { (Indicadores, Orçamento, Qualidade da Produção } \\
\text { Legislativa, Relatórios de Gestão, etc); Pesquisas de } \\
\text { Percepção Cidadã; Plano de Metas; Audiências Públicas; } \\
\text { Participação em Conselhos de Políticas Públicas e } \\
\text { Associações de Bairro. Na comunicação, assim como há } \\
\text { presença de grupos fortes de mídia, é feito o uso de canais } \\
\text { alternativos como as mídias sociais - Facebook, Twitter, } \\
\text { Youtube, Blogs - para comunicar, engajar e divulgar o } \\
\text { trabalho realizado. }\end{array}$ \\
\hline Regras e Normas & $\begin{array}{l}\text { No que se refere a questões institucionais, os dois } \\
\text { Institutos seguem as atribuições estatutárias. Em relação } \\
\text { aos projetos, atividades e ações há reuniões entre as } \\
\text { pequenas equipes que compõem a sua estrutura. Em } \\
\text { Florianópolis, o Comitê Gestor coordena a iniciativa e } \\
\text { reúne eventualmente o comitê consultivo ampliado. }\end{array}$ \\
\hline
\end{tabular}

Fonte: elaborado pelo autor.

Nas três experiências, a busca por uma cidade justa, democrática e sustentável a partir de projetos, atividades e sistemas de monitoramento envolvendo diferentes atores locais geram efeitos, alguns mais visíveis outros menos, sobre a governança democrática e o sistema de accountability. Ao mesmo 
tempo em que fica perceptível que os atores envolvidos nas iniciativas representam apenas uma parcela da sociedade, que de alguma forma já conhecem o jogo político e como acessar os canais institucionais a partir da sua expertise, há evidências que apontam no sentido de fortalecimento da governança local. É utopia imaginar que haverá uma ampla participação de todas as instituições, porém o grupo que se envolve nestas iniciativas é mais homogêneo do que heterogêneo, este último, pressuposto essencial à governança democrática. Esse talvez seja um dos desafios, comum as três iniciativas.

Em termos de discurso, percebeu-se que os entrevistados fazem referência a uma visão pluralista de cidadania e também trazem uma reflexão ou alerta sobre as deficiências da democracia representativa, seus instrumentos e instituições. É a partir destas reflexões que as lideranças entrevistadas destacaram a importância de contemplar em suas ações projetos de conscientização cidadã, de esclarecimento sobre os sistemas de controle e responsabilização do poder público como, por exemplo, o controle exercido sobre o legislativo e próprio instrumento do Plano de Metas.

Mecanismos tradicionais como o Plano Plurianual, a Lei Orçamentária Anual e a Lei de Diretrizes Orçamentárias são frequentemente questionados pelas lideranças entrevistadas sobre a lógica mais centralizada de decisão e de que os instrumentos de participação disponibilizados são frágeis. Tal questionamento, por si só, evidencia uma percepção de que os formatos atuais e tradicionais de acionamento e responsabilização não são suficientes. Sob esta lógica, a accountability de procedimentos, a accountability de desempenho e a accountability horizontal estão presentes em sua ação, com o apontamento de restrições à sua efetividade. Assim, o trabalho destas experiências busca aproximar-se daquilo que se convencionou chamar accountability social.

Em Florianópolis, a ênfase na coordenação dos trabalhos pelo Comitê Gestor, na questão técnica de monitoramento e acompanhamento dos indicadores, na especialidade da consultoria contratada em sistematizar os dados, na construção dos desafios da cidade, na expertise do Grupo de Pesquisa e do Observatório Floripa 
Cidadã e a chamada da Prefeitura, para objetivamente apresentar o Plano de Metas, trazem indícios de uma accountability produzida por uma rede de especialistas, focada no desempenho, que se utiliza também da rede horizontal de accountability para produzir informação, pressionar a aprovação do plano e monitorar a sua execução pela Prefeitura. Essa informação tornada pública por estas instituições, e por outros meios e canais utilizados pelas experiências, para pautar o debate na agenda da cidade visa, ao final, qualificar a prestação de contas e o debate envolvendo essa agenda. A própria participação do cidadão pode gerar sanções simbólicas e políticas aos gestores, inclusive eleitorais. Este é, pelo menos, o contexto idealizado e esperado para o futuro por aqueles que integram a iniciativa, evidenciando um contexto que tende à accountability social.

Em Ilhabela e Ilhéus, embora o Plano de Metas não tenha sido efetivado pelo Executivo Municipal, essa dimensão de monitoramento da atividade governamental se estabelece sobre a Câmara de Vereadores, acompanhando licitações e contratos, a qualidade da produção legislativa e do trabalho dos vereadores, etc, com a apresentação de relatórios periódicos em audiências públicas, encontros dos conselhos municipais e sistematizações publicadas nos sites da instituição. Em Ilhéus há ainda o acompanhamento do processo envolvendo os Planos Municipais da Mata Atlântica, que envolvem o governo Estadual e Federal, e em Ilhabela o acompanhamento da Plano Municipal de Saneamento Básico.

Em Ilhabela e Ilhéus o controle sobre a atividade governamental proporciona o acionamento de mecanismos de accountability para além dos tradicionais. Há um engajamento com a mídia tradicional em menor escala do que a encontrada em Florianópolis e o uso da mídia social e da mídia alternativa como possibilidades de debater a cidade em várias frentes, visando qualificar não só o processo eleitoral, mas visando mudar a postura dos governantes para que estes sejam mais accountable. Em Ilhéus, a parceria com o Teatro Popular representa uma estratégia inovadora de reflexão sobre a cidade, sobre os casos de corrupção e sobre a importância da qualificação da cidadania. 
Portanto, os casos analisados expressam a existência de um sistema de accountability social em amadurecimento. Porém, da mesma forma que em Florianópolis, a lógica do desempenho e da accountability de rede horizontal convivem com a perspectiva de accountability social. Nas três experiências há, para efeitos de modelo de análise, uma convivência entre diferentes perspectivas de accountability.

Em síntese, a figura a seguir aponta as relações de accountability evidenciadas com maior frequência nas três cidades:

Figura 6 - Accountability Relacional em Florianópolis, Ilhabela e Ilhéus

\section{ACCOUNTABILITY RELACIONAL}

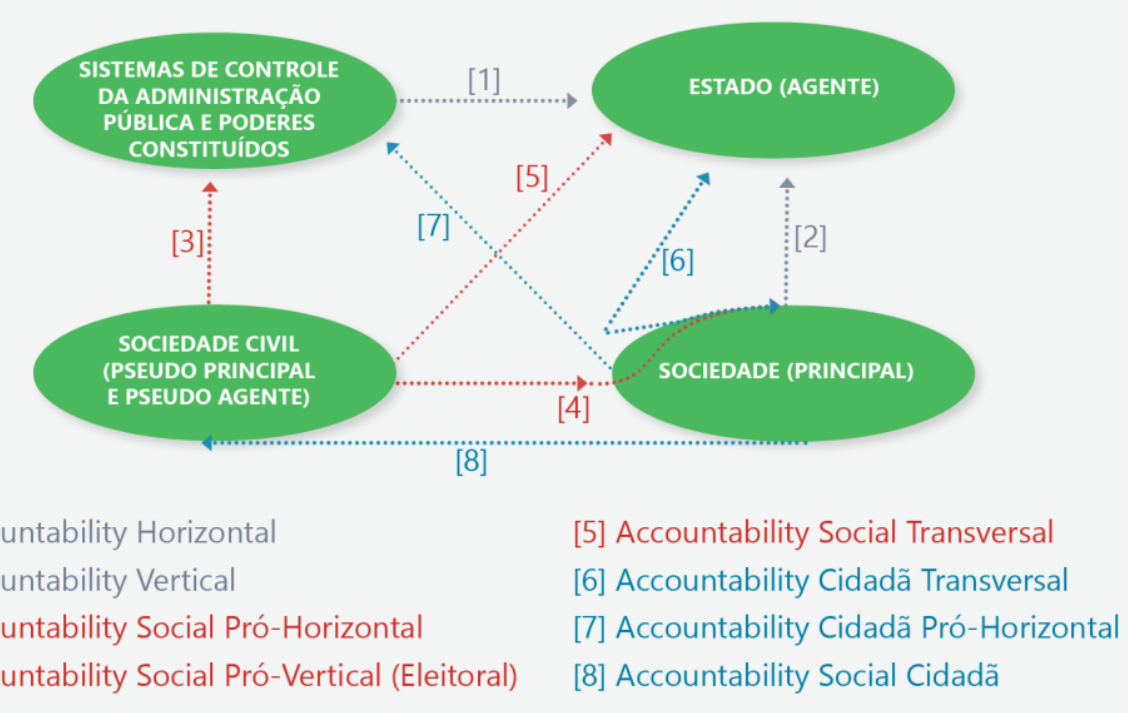
[1] Accountability Horizontal
[5] Accountability Social Transversal
[2] Accountability Vertical
[6] Accountability Cidadã Transversal
[3] Accountability Social Pró-Horizontal
[8] Accountability Social Cidadã
[4] Accountability Social Pró-Vertical (Eleitoral)

PERSPECTIVA DE ACCOUNTABILITY IDENTIFICADAS NO TRABALHO DAS EXPERIÊNCIAS:

Florianópolis: [3] e [4]

Ilhabela: [3] - [4] - [5] e [8]

Ihéus: [3] - [4] - [5] e [8]

Fonte: Elaborado pelo autor.

Voltando ao conceito de confronto político, ele se concretiza quando, nas três experiências, a mobilização oriunda do processo de articulação dos diferentes 
atores visa gerar efeitos ou incidir na agenda governamental e no processo da cidadania.

Nas três experiências buscou-se identificar resultados e influências desse processo em curso, perguntando-se aos entrevistados sobre os resultados verificados a partir do trabalho desenvolvido pelas iniciativas. Em linhas gerais, os âmbitos de incidência demonstraram uma perspectiva de influência relacionada direta e indiretamente sobre a governança democrática e o próprio sistema de accountability.

Embora estes âmbitos estejam interligados, alguns exemplos em cada iniciativa podem ser destacados. Na sequência será apresentada uma análise sobre estes âmbitos, com os principais destacados na figura a seguir:

Figura 7 - Âmbitos de Incidência

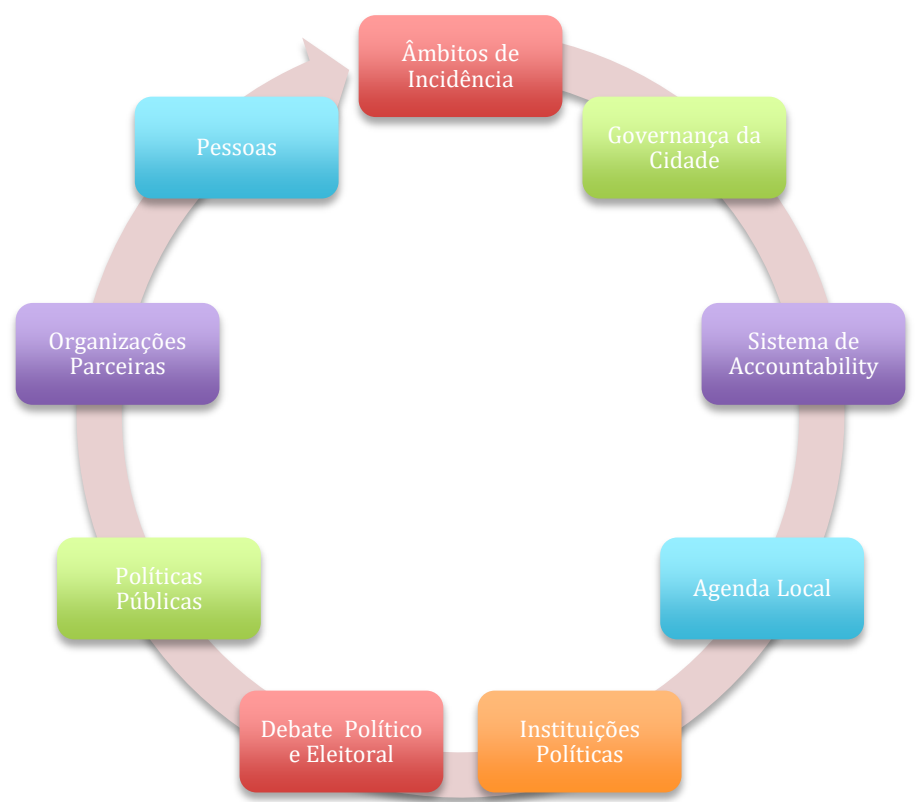

Fonte: elaborado pelo autor. 
Com relação a governança da cidade, as iniciativas, pelo próprio caráter de articulação comunitária que desenvolvem na cidade, visam fortalecer as instituições e os espaços de governança que já existem, qualificando-os e transformando algumas de suas práticas, visando também ampliar o rol de instituições e espaços de governança existentes. Talvez exemplo mais expressivo desse âmbito de incidência ocorra em Ilhabela, a partir de seu trabalho com os Conselhos Municipais, com o Instituto participando ativamente deles, compartilhando informações, sistematizando dados e relatórios que possam ser utilizados como instrumento político para responsabilizar os gestores, ao mesmo tempo em que sensibilizam as pessoas que participam dos conselhos e divulgam a relevância de seu trabalho para a sociedade. Essa estratégia de trabalho em Ilhabela também evidencia incidência sobre as diferentes perspectivas de accountability. Em Florianópolis, o espaço de discussão sobre o Plano de Metas também seria um exemplo neste sentido.

No que se refere a agenda local, isso fica devidamente explícito nas iniciativas pela própria natureza da ação coletiva que tem como pano de fundo uma preocupação com a cidade. Exemplos de incidência encontrados sobre a agenda em Ilhéus, por exemplo, é a articulação da inciativa com o Sebrae para trabalhar a questão da Economia Criativa. A partir dos ativos disponíveis nos bairros e mobilizando associações e conselhos locais capacita-se as pessoas para alguma forma de geração de trabalho e renda, trabalhando a frente da justiça social. Ainda em Ilhéus, o resgate da cultura local dos bairros é algo que impacta na agenda da cidade, ao discutir questões sobre aquele território. Em Ilhabela, uma das evidências a destacar seria a ação do Dia Mundial sem Carro, em o que Instituto alugou barcos que faziam o translado das pessoas entre pontos específicos da ilha, demonstrando a viabilidade deste modal e os impactos disso na mobilidade urbana. A Prefeitura, após essa ação, começou a construir píeres para futuras instalações de transporte. 
Sobre o debate político, há variadas formas de promovê-lo. Em Florianópolis, a participação de um grupo de mídia facilitou o trabalho de sensibilização sobre a iniciativa. Em Ilhéus, a participação semanal de alguém do Instituto em Programa de Rádio discute temas relacionados a cidadania, a política e ao papel do cidadão. Isso somado à questão cultural promovida pelo Teatro Popular de Ilhéus, que contribui para formar opinião. Os projetos de conscientização cidadã são outra frente que potencializa os efeitos desse debate político sobre a cidade e sobre as pessoas, tanto em Ilhéus como em Ilhabela. Outra forma de incidência sobre o debate político refere-se ao processo eleitoral, como, por exemplo, a assinatura de cartas compromisso com a Plataforma Cidades Sustentáveis e o comprometimento com a execução do Plano de Metas pelos candidatos. Em Florianópolis, segundo relato dos entrevistados, o próprio documento contendo os desafios da cidade foi utilizado como pauta no debate eleitoral, com os candidatos ao executivo.

Em termos de incidência em instituições políticas e políticas públicas as iniciativas apresentam diversos exemplos. Tanto o instrumento do Plano de Metas trabalhado pelas três iniciativas, como o Plano Municipal de Saneamento Ambiental em Ilhabela e o incentivo para o desenvolvimento dos Planos Municipais da Mata Atlântica em Ilhéus são indícios de participação e influência destas iniciativas sobre as instituições políticas. Em um primeiro momento elas pressionam estas instituições para incluir as questões consideradas prioritárias. Em um segundo momento, elas exercem uma perspectiva de monitoramento sobre a execução das políticas públicas. Em Ilhéus, por exemplo, o Instituto tem acompanhado a implantação do seu Plano Municipal da Mata Atlântica. Em Ilhabela, uma reunião anual com a participação dos principais envolvidos no governo com a questão do saneamento apresentam para a sociedade a execução da política municipal de saneamento básico. Em Florianópolis, o primeiro encontro para a apresentação do status do Plano de Metas pela Prefeitura e o desenvolvimento do próprio instrumento, articulados pela sociedade civil, representam um exemplo nesse contexto. 
As organizações parceiras, quando reunidas através desse processo de articulação local trocam expertises e geram aprendizagem conjunta sobre a cidade. Elas socializam o repertório e aprendem com a ação de cada iniciativa. Nas três cidades, quando perguntado sobre a aprendizagem com a participação nestas iniciativas, surgem declarações no sentido de se aprender sobre a cidade e sobre a governança das próprias organizações e redes, de conhecer projetos comuns em instituições diferentes, em possibilitar que todos estes esforços sejam integrados agora em uma única ação.

Por último, mas não menos importante, o principal âmbito de incidência que as iniciativas pretendem com seu trabalho é incidir sobre pessoas, sobre cidadãos. Nas três iniciativas comenta-se sobre a impossibilidade de, no momento, mensurar esse trabalho, mas que se percebem mudanças na postura de participação e controle sobre a atividade governamental. O discurso dos atores entrevistados destaca a importância de fortalecer o cidadão, para que ele exerça o controle sobre a cidade. Como um ator político por excelência, o cidadão precisa agir não apenas no contexto eleitoral, dando sua resposta pelo seu voto, mas também engajando-se no cotidiano desta cidade, usufruindo do que ela tem a oferecer de forma equilibrada e que garanta a sustentabilidade dela para os que hoje nela residem e para as futuras gerações. Questões estas centrais para a discussão e a efetivação da governança democrática e da accountability social, que resultariam em mudanças nas práticas políticas e seus consequentes reflexos sobre as instituições políticas e a cultura política.

Resgatando-se o conceito de incidência adotado no modelo teórico podemos concluir que, sobre a socialização política das pessoas e dos grupos participantes que o aprendizado social, com o compartilhamento de projetos e práticas, relatado por alguns dos entrevistados, reforça o argumento de socialização política do repertório e dos instrumentos utilizados.

A incidência sobre instituições e práticas políticas é o mais destacado nas três experiências. A disseminação de informações, a produção de indicadores, a realização de pesquisas, a busca pela transparência pública, o fomento à 
participação popular e a sua qualificação, a inserção destes grupos na montagem da agenda e no monitoramento de políticas públicas, inserir-se no espaços de governança e buscar seu fortalecimento estão entre as evidências mais visíveis em termos de efeitos sobre às instituições e as práticas políticas locais.

No que se refere aos efeitos sobre a cultura política, o plano discursivo das experiências traz fortemente essa discussão. As práticas de governança democrática $e$ as diferentes perspectivas de accountability trabalhadas pelas iniciativas reforçam a busca destas ações coletivas por uma cidade sustentável, em que o cidadão seja o ator político por excelência. Esses efeitos são mais difíceis de serem visualizados e poderão ser evidenciados à longo prazo, com método de pesquisa próprio, tendo em vista as inciativas ainda serem recentes. Por fim, essas são algumas evidências de âmbitos de incidência encontrados nas três experiências que poderão ser elaborados em maior profundidade em futuros estudos, nestes e em outros âmbitos da cidade, trazendo novos aportes teóricos e novas articulações em categorias de análise.

\section{Conclusões}

Tendo em vista a pergunta de pesquisa, as análises refletiram um recorte analítico construído a partir da Teoria da Mobilização Política e do Confronto Político. As dimensões da governança democrática e da accountability social, incorporadas ao modelo teórico e analisadas a partir do conceito de mobilização de estruturas da teoria, permitiram identificar nos casos a presença, por vezes mais visível, por outras menos, destas dimensões. Por último, efeitos gerados por elas permitiram identificar âmbitos de incidência não apenas na agenda da cidade, nas instituições e nas políticas públicas, mas nos grupos e nas pessoas que de alguma forma estão envolvidas com o trabalho articulado pelas experiências. 
Buscando compreender a ação política das redes de cidades, o repertório, traduzido pelos valores de justiça, democracia e sustentabilidade, é o grande articulador e mobilizador destas redes no continente latino-americano, expressando claramente a sua dimensão política. Marcado por desigualdades sociais e urbanas comuns a muitos países, o ideal ganhou força política em busca de superar a cidade excludente, característica do continente. Essa força política está relacionada tanto ao aumento da interconexão global entre as pessoas e grupos de instituições que compartilham de um mesmo ideal, como do reconhecimento de problemas comuns em suas cidades.

Colocado em intenção pelas diversas iniciativas que compõem estas redes e articulando-se a outras instâncias locais, nacionais e transnacionais, o repertório traz reflexos sobre a mobilização política de grupos da cidade, que embora diversos, são homogêneos. Sua ação política vêm ocupar os espaços de governança da cidade, expressando-a, na medida em que é mais uma instância que a compõem, e fortalecendo-a, quando articula-se a outras organizações e mecanismos para exercer controle e sanção sobre as instituições políticas e os representantes eleitos.

A partir das experiências analisadas, percebeu-se uma influência mútua entre governança e accountability na prática destas ações coletivas. Ao buscar maior transparência, estimular o acesso à informação, monitorar a atividade governamental, a execução de políticas públicas e capacitar a cidadania, as iniciativas geram mudanças na governança local, que trazem efeitos para o exercício da accountability. Entendida a partir de uma perspectiva relacional, a 
prática de accountability influencia e é influenciada pela governança local e pelas iniciativas. Como destacado nos resultados, embora expressando diferentes modalidades de accountability, as três iniciativas, a partir do discurso dos atores e dos projetos realizados aproxima-se, cada uma com suas particularidades, do conceito de accountability social.

As iniciativas também relatam fortemente uma percepção da importância da dimensão política e de formação para a cidadania para concretizar o repertório. No que se refere aos âmbitos de incidência apresentados, a dimensão política também ganha relevância. Se as iniciativas geram aprendizagem social, criam novos espaços de discussão sobre as cidades, buscam qualificar o debate político e eleitoral e fortalecer a governança da cidade, elas estão contribuindo para a socialização de um ideal de cidade nas pessoas, nos grupos participantes, nas instituições e práticas políticas, pelo próprio exercício da cidadania e da política, visando, em último caso, uma mudança cultural expressa na passagem de uma cidade excludente para uma cidade sustentável. Uma passagem que é complexa devido a diversas circunstâncias, entre elas, o padrão de relacionamento entre Estado e sociedade nos diversos níveis, a cultura política de cada cidade, a qualidade da participação e dos canais disponibilizados para o seu exercício, entre tantos outros.

Por outro lado, apesar dos avanços identificados e do potencial fortalecimento da governança democrática e do sistema de accountability, alguns desafios ficam evidentes. A afirmação deste projeto político de cidades sustentáveis 
representa para a sociedade civil um desafio, na medida em que visa conciliar distintos atores e interesses na sua construção. Nesse contexto, ela precisa estar sempre atenta aos princípios maiores que regem a sua atividade na construção de seus apoios políticos e financeiros, na elaboração de seus projetos e na utilização de seus instrumentos, visando garantir a autonomia deste projeto, frente a tantos interesses e opiniões distintas.

Outro desafio é a relação com o poder público municipal. Há uma incompatibilidade entre lógicas de ação da sociedade civil, mais fluidas e dinâmicas, com as lógicas do poder público, ainda mais centralizadas e hierárquicas, apesar dos esforços recentes de horizontalização da governança. Enquanto o ativista tem pressa em desenvolver soluções sustentáveis para a sua cidade, a administração pública tem seus tempos e cronogramas construídos a partir do que lhe é permitido fazer, de suas leis, regulamentos e prazos protocolares, além das pressões, por vezes mais visíveis, por vezes menos, dos interesses de exploração do território, de ocupação da cidade. Enfim, pressões que nem sempre são colocadas publicamente, mas que interferem na tomada de decisão dos prefeitos, vereadores e gestores públicos. Nesse sentido, cria-se um embate que pode levar ao desgaste no relacionamento, o que não é saudável para o estabelecimento de um novo padrão de relacionamento entre Estado e sociedade, calcado na participação. Mais uma questão relacionada a este desafio é a própria visão do que seja uma cidade sustentável para as iniciativas e para o poder público municipal. 
Outro desafio percebido para as três experiências é a articulação e o entendimento de que os problemas da cidade não derivam apenas de questões locais. A implantação de um plano de metas, a depender da área e da complexidade, demanda articulação estadual e federal. A dimensão territorial tanto dos problemas quanto das soluções é um desafio em termos de gestão dos projetos realizados por estas iniciativas, como também de governança. O reconhecimento das regiões metropolitanas e a articulação entre estas iniciativas com outras semelhantes é essencial para fortalecer sua ação. A mudança recente do nome da rede latinoamericana, incluindo o "Território" pode representar uma evidência deste ponto relatado. Sua inserção em outras redes nacionais ou transacionais em pautas específicas, mas relacionadas aos seus eixos de atuação, é outro fator importante de articulação que agrega metodologias, experiências e saberes.

Voltando-se ao modelo teórico, ele representa uma simplificação da realidade que buscou articular três categorias analíticas, sendo as análises um reflexo produzido a partir deste recorte. Uma das limitações da pesquisa foi a construção do quadro de oportunidades e restrições políticas do contexto local a partir do discurso dos atores. Da mesma forma, o contexto de surgimento destas redes no continente latino-americano, não aprofundou as mesmas variáveis que levam ao seu surgimento. $\mathrm{O}$ modelo demonstra mais fortemente a disseminação do repertório destas redes, a partir de seus valores e práticas, colocando em interação os contextos latino-americano, das iniciativas e o contexto teórico-empírico. Por fim, o modelo teórico proposto, devido a proposta metodológica de objeto 
construído em interação com o campo, adotada neste trabalho, ao mesmo tempo em que representou um parâmetro para a estruturação das análises, é também um produto dessa interação teoria-campo-definição do objeto de pesquisa.

\section{Referências}

AVINA. (2014) O trabalho da Avina na iniciativa Cidades Sustentáveis. 2014. Disponível em: 〈http://informeavinazor2.org/portugues/ciudades.shtml〉 Acesso em: Io ago.

BEVIR, M. (20II). Governança Democrática: uma genealogia. Revista de Sociologia Política. Curitiba: v. I9, n. 39, p ro3-II4.

BEVIR, M. (2010). Democratic Governance. New Jersey, Princeton University Press.

CÁCERES, P. (2014). Planes de Metas como innovaciones en los processos de rendición de cuentas en el nível local. Experiencias en el marco de la Red Latino Americana por Ciudades Justas, Democráticas y Sustentables. Cordoba: 2014.

CARLOS E. (20II). Contribuiçóes da Análise de Redes Sociais às Teorias dos Movimentos Sociais. Revista de Sociologia Política. Curitiba. v. 19, n. 39. p. 153-166.

CEFAI; D. (2007). Introduction générale. In: Porquoi se mobilise-t-on? Les théories de l'action collective. Paris: Éditions La Découverte, 2007, pp. 7-32.

COHEN, Jean L. (2003). Sociedade Civil e Globalização: Repensando Categorias. Revista de Ciências Sociais. Rio de Janeiro: v. 43, n. 3.

DELAURIERS, Jean-Pierre; KÉRISIT, Michele. (2008).O delineamento da pesquisa qualitativa. In:

POUPART, et al. A pesquisa qualitativa: enfoques epistemológicos e metodológicos. Petrópolis, RJ: Vozes.

DENHARDT, J. V.; \& DENHARDT, R. B. (2007). The New Public Service: serving, not steering. Expanded edition. Nova York: M. E. Sharp, Inc., 2007.

DENHARDT, B. (2012) Teorias da Administrac,ão Pública. Tradução: Francisco Gabriel Heidemann. São Paulo: Cenage Learning.

ETHOS. (2014). Cidades sustentáveis: cidades sustentáveis: como as empresas podem contribuir. São Paulo: ETHOS, 2009. Disponível em: <http://wwwi.ethos.org.br/EthosWeb/arquivo/o-A-a9931-

2585\%20Cidades\%20Sustent\%C $3 \%$ Arveis\%20Ethos\%20-\%20FINALIZADO.pdf . Acesso em: is jun. 
. (2014). Rede nossa São Paulo. São Paulo: ETHOS, 2014. Disponível em: $<$ http://www3.ethos.org.br/conteudo/projetos/apoiados/segundo-projetoapoiado/\#. U53 $\mathrm{Sw}_{5} \mathrm{RdWRM}>$. Acesso em: I8 mar.

FIABANE, Danielle. (20II). Controle social: um novo frame nos movimentos sociais. Dissertação (Mestrado em Administração) - Escola de Administração de Empresas de São Paulo, São Paulo, 20 Ir.

FIABANE, Danielle; ALVES, Mário Aquino; BRELÀZ, Gabriela de. (2014). Social accountability as an innovative frame in civic action: the case of Rede Nossa São Paulo. Voluntas.

GAVENTA, John. (2002). Towards participatory local governance: Six Propositions for Discussion. Institute of Development Studies.

GÓMEZ, J. M.; DELGADO, A. C. (20II). Accountability Social e o problema da corrupção na Indía, Brasil e África do Sul. Núcleo de Análises de Economia e Política dos Países - BRICS. Centro de Estudos e Pesquisa BRICS,

GOETZ, A. M., \& JENKINS, R. (20oI) Hybrid forms of accountability: citizen engagement in institutions of public-sector oversight in India. Public Management Review, v.3, n.3, p. 363-83.

GOETZ, A. M. (2003). Reinventing Accountability: a new twist on a key concept in democratic theory. Community of Practice on Social Accountability Launch.

GOHN, M. da G. (2oII) Sociologia dos Movimentos Sociais: um balanço das teorias clássicas e contemporâneas. Canadian Journal of Latin American and Caribean Studies. V. 36, n. 72, p. 199-227.

GOHN, M. da G. (2010) Teoria dos Movimentos Sociais: Paradigmas Clássicos e Contemporâneos. 8a ed. São Paulo: Loyola.

HEIDEMANN, Francisco G. (2009). Ética de responsabilidade: sensibilidade e correspondência a promessas e expectativas contratadas. In: HEIDEMANN, Francisco G.; SALM, José F. (Orgs.). Políticas públicas e desenvolvimento: bases epistemológicas e modelos de análise. Brasília: UnB, p. 30 I-9. $^{-}$

HERNANDEZ QUINÕNES, A. DEVILCHEZ, D. (2014). Iniciativas de transparência y accountability en America Latina: naturaliza, tipologia e incidência en la democracia y el desarrollo. Abril: 2014.

HERNANDEZ QUINÕNES, A. (20II). Análisis y Estudio de Experiencias de Accountability Social en América Latina. CIDER - Centro de Estudios Interdisciplinarios Sobre el Desarrollo. (Informe final de investigación - Convenio de cooperación entre Fundación Corona y Universidad de Los Andes, apoyo Fundación Corona y Fundación Avina - Red Latinoamericana por Ciudades Justas y Sustentables). Bogotá, CIDER.

ISUNZA, E.; LAVALLE, G. A. (2010) Precisiones conceptuales para el debate contemporáneo sobre la innovación democrática. Participación, controles sociales y 
representación. In: ISUNZA, Ernesto; LAVALLE, Gurza Adrian. (coordinadores). La innovación democrática en América Latina. Tramas y nudos de la representación, la participación y el control social. México, Universidad Veracruciana, CIES.

JIMÉNEZ, M. C. (2012). La Importancia Del Accountability Social Para La Consolidación De La Democracia En América Latina. Revista de Relaciones Internacionales, Estrategia y Seguridad, v; 7, n. 2, julio-diciembre, pp. 97- 130. Universidad Militar Nueva Granada Bogotá, Colombia.

McADAM, D.; TARROW, S.; TILLY, C. (2009). Para mapear o confronto político. Revista Lua Nova. São Paulo, v. 76, p. II-48.

MONCRIEFFE, John. (20II) Relational Accountability: Complexities of Structural Injustice. Zed Books. London.

O’DONNELL, G. (1998). Accountability horizontal e novas poliarquias. Revista Lua Nova. São Paulo: n. 44: 27-54.

PEREIRA, Maurício Broinizi. (2014). A rede social brasileira por cidades justas e sustentáveis. São Paulo, 2014. Disponível em: 〈http://www.nossasaopaulo.org.br/portal/arquivos/ArtigoRedeCidades.pdf〉

Acesso em: 20 jun.

PERUZZOTTI, E. (2012) La politica del accountability social en América Latina. Documento de trabajo.

PERUZZOTTI, E; SMULOVITZ, C. (2002) Accountability Social: la outra cara del control. Controlando la Política: Ciudadanos y Medios en las Democracias Latinoamericanas. Buenos Aires: Grupo Editorial Temas.

REDE NOSSA SÃO PAULO. (2014). Institucional. São Paulo: RNSP, 2014. Disponível em: 〈http://www.nossasaopaulo.org.br/institucional〉. Acesso em: I4 jun.

RED CÓMO VAMOS. (2014). Institucional: Red de Ciudades Cómo Vamos. Bogotá, 2014. Disponível em: <http://www.bogotacomovamos.org/acerca-de/redde-ciudades/> Acesso em: I4 mar. 2014.

RLACTJDS. (2014). Ciudades e reds. 2014a. Disponível em: $<$ http://redciudades.net/blog/ciudades/〉. Acesso em: I9 jun. 2014.

ROCHA, Arlindo C. (20II). Accountability na administração pública: modelos teóricos e abordagens. Contabilidade, Gestão e Governança, Salvador, v. I4, n. 2, p. 82-97, mai./ago.

TARROW, S. (2009). O poder em movimento: movimentos sociais e confronto político. Tradução: Ana Maria Sallum. Petrópolis, RJ: Vozes.

WORLD BANK (2014). Social Accountability: what does it means for the worl Bank. In: Social Accountability Sourcebook. 
WORLD BANK (2013). Theory for Change. In: Rethinking Social Accountability in Africa: Lessons from the Lwanachi Programme. Lwanachi Programme.

UNITED NATIONS (2010). Fostering Social Accountability: From principle to practice. Guindance Note. Democratic Governance. 